\title{
Comparative marine biodiversity and depth zonation in the Southern Ocean: evidence from a new large polychaete dataset from Scotia and Amundsen seas
}

\author{
Lenka Neal $^{1} \cdot$ Katrin Linse $^{2} \cdot$ Madeleine J. Brasier $^{1} \cdot$ Emma Sherlock $^{1}$. \\ Adrian G. Glover ${ }^{1}$
}

Received: 20 January 2017 / Revised: 11 May 2017 / Accepted: 12 May 2017 / Published online: 29 June 2017

(C) The Author(s) 2017. This article is an open access publication

\begin{abstract}
Based on a dataset of 16,991 and 307 morphospecies of polychaete worms collected from 58 epibenthic sledge deployments across the Scotia and Amundsen Seas, we show that the structures of their shelf, deep-shelf and slope communities are composed of distinct polychaete assemblages spanning regions with "high", "intermediate", and "low" biodiversity. Depth has been identified as the main factor structuring the polychaete communities in both seas, countering the prevalent notion of extended eurybathy of the Southern Ocean benthos. From an evolutionary perspective, this strong dissimilarity between shelf and slope fauna could be interpreted as evidence for survival in shelf refugias, rather than migration into deeper waters during glacial maxima. The previously unsampled Amundsen Sea is shown to be diverse, harbouring a high level of taxonomic novelty, with many species new to science. The polychaete community of the inner shelf in the Amundsen Sea (Pine Island Bay) has also been shown to be of deep-sea character, likely due to intrusion of the Circumpolar Deep Water onto the shelf. In the Scotia Sea, our data support the notion of relatively high biodiversity of waters around the South Orkney Islands, South Georgia, and Shag Rocks (all
\end{abstract}

Communicated by J. Gutt

Electronic supplementary material The online version of this article (doi:10.1007/s12526-017-0735-y) contains supplementary material, which is available to authorized users.

Adrian G. Glover

a.glover@nhm.ac.uk

1 Department of Life Sciences, The Natural History Museum, Cromwell Rd, London SW7 5BD, UK

2 British Antarctic Survey, High Cross Madingley Road, Cambridge CB3 0ET, UK recently established as Marine Protected Areas) and depressed diversity in the extreme environment of Southern Thule.

Keywords Antarctica $\cdot$ Southern Ocean $\cdot$ Amundsen Sea $\cdot$ Scotia Sea $\cdot$ Annelida $\cdot$ Polychaeta $\cdot$ Taxonomy $\cdot$ Deep Sea $\cdot$ Depth zonation

\section{Introduction}

The deep Southern Ocean that surrounds the Antarctic continent is still largely an unexplored wilderness, where ocean expeditions routinely bring up samples in which the majority of species are new to science (e. g. Hilbig et al. 2006; Brandt et al. 2007a, 2007b). An important question is if the Southern Ocean is not just a source of such taxonomic novelty, but also a "hotspot" of biodiversity of global significance that may be impacted by future anthropogenic stressors such as climate change and the development of fisheries. Based on a new and large dataset of annelid worms which we make publicly available, we show in this paper that the community structure of the shelf and deep-shelf west Antarctic is highly heterogeneous and composed of regions with "high", "intermediate", and "low" biodiversity.

The remote and extreme environment of Antarctica and its surrounding Southern Ocean has attracted scientific exploration since the mid-nineteenth century, including early expeditions such as the HMS Challenger, RV Belgica, and RRS Discovery. It has historically been considered a species-poor environment, with diversity constrained by low temperatures, extreme seasonality of productivity, isolation by the Antarctic Circumpolar Current and the lack of enough "time" since the last glaciation for speciation and radiation to occur (e.g. Dell 1965; Crame 2000). Taxonomic and biogeographic studies have tended to reinforce this point noting for example the 
low diversity in decapod crustaceans (Clarke and Johnston 2003), molluscs (Crame 2000) and similarities to deep-sea fauna (Lipps and Hickman 1982; Brey et al. 1996). In terms of general macroecological theory, high latitude environments are considered depauperate relative to temperate and tropical regions. The prevalence of this pattern is not thought to be controversial, but the precise causes of it are subject to intense and long-running debate over the years (e.g. Rohde 1992), and its prevalence in deep-water and applicability to Southern Ocean is certainly poorly constrained (e.g. Rex et al. 1993; Gray 2001).

Quantitative comparisons of Antarctic marine biodiversity are still rare, and did not start until the mid 1960s with a study of molluscs that suggested that diversity was low, and the continent was undergoing a slow invasion of species from surrounding waters (Dell 1965). In the mid-1970s, a number of inshore quantitative studies took place in the Antarctic Peninsula region which reported, for the first time, relatively high numerical diversity (Shannon-Weiner index) based on grab sampling in Arthur Harbour and Chile Bay (Lowry 1975; Richardson and Hedgpeth 1977; Gallardo 1977). During the 1980s and 1990s, both original data papers and review papers were generally equivocal on whether the Southern Ocean was a "diverse" community, with high diversity reported in some groups but not in others, and a general emerging trend of the significance of endemism (driven by isolation) and the role of disturbance (e.g. Dayton 1990; Clarke 1996). Arntz et al. (1994) provided an overview of the knowledge existing at the time. Gray (2001) was certainly of an open mind as to whether the Antarctic marine benthos was diverse or not, and highlighted the many problems in the comparative method such as confusion of scales and inadequate data.

The mid-2000s saw a number of publications starting to emerge from the German EASIZ and ANDEEP programs including a large number of new species records, but the data were hard to compare globally (e.g. Hilbig 2004; Brandt 2005). A quantitative comparison of the Magellan Shelf and the Weddell Shelf (Montiel et al. 2005) found that, surprisingly, diversity was broadly similar and that 28 of 334 species were shared across the Antarctic Circumpolar Current, based on morphological data. A meta-analysis of mollusc diversity showed that endemism is generally high in the Antarctic, but diversity reduced (Linse et al. 2006). However, some data have showed that "cosmopolitan" deep-sea fauna are prevalent in the Antarctic shelf, challenging the concept of Antarctic endemism (Schüller and Ebbe 2007). A summary of the large ANDEEP datasets (Brandt et al. 2007a, 2007b) highlighted the prevalence of "new" biodiversity (i.e. the relative numbers of undescribed species) and stressed that degrees of endemism varied among taxa, but did not make direct global comparisons of Antarctic biodiversity. In global comparisons, Antarctic shelf diversity (of polychaetes) has been shown to be higher than Arctic sites, similar to general bathyal sites and lower than most abyssal sites but comparative data are rare (Neal et al. 2011). Gutt et al. (2004) estimated that the total expected number of macrozoobenthic species for the entire Southern Ocean shelf lies between 11,000 and 17,000 suggesting "intermediate" species richness when compared to other selected habitats.

The majority of Antarctic benthic community studies to date have stressed the importance of these two main macroecological patterns (endemism and diversity), against a backdrop of the unusual environmental variables associated with the Antarctic shelf and slope. These regions are extreme in terms of their temperature, degree of seasonality and isolation by the Antarctic Circumpolar Current. The Antarctic shelf is geographically vast and in general much deeper than other continental shelves, with an average depth of $450 \mathrm{~m}$ and a large number of shelf basins and troughs that are depressed to over $1000 \mathrm{~m}$ in places, partly due to ice-loading of the continent but predominantly as a result of past ice scouring occurring during previous glaciations (Huybrechts 2002). The majority of the sea floor hence lies well below the euphotic zone and is subject to seasonality in terms of food input from surface production (Gutt and Piepenburg 2003; Smale and Barnes 2008; Glover et al. 2008).

Studies of the Antarctic marine fauna have often focused on the role of these variables in driving adaptive strategies and shaping the present day fauna (see Clarke et al. 2004). For example, slow growth and development, an emphasis on brooding and lecithotrophic reproductive strategies (Thorson 1950; Pearse 1991), a trend toward gigantism in invertebrates (Chapelle and Peck 1999; Peck 2002) and extended eurybathy (Brey et al. 1996). The eurybathy in particular has been interpreted in ecological terms (e.g. constant physical properties of water column) or evolutionary terms as adaptation to migration into deeper-water during glacial maxima (e.g Kussakin 1973; Brey et al. 1996). Glacial maxima are thought to be of particular importance in the shaping the benthic fauna of the Southern Ocean as grounded ice sheets extended over much of the continental shelf, destroying much of the available habitat and restricting fauna to isolated refugia (e.g. Thatje et al. 2005).

Despite many decades of sampling, the role of these unusual environmental factors in shaping the diversity and endemism of Antarctic fauna is still poorly constrained. In particular, there is a lack of comparative data within the large expanse of the Antarctic continental shelf itself, where some vast regions remain unsampled (Griffiths et al. 2011; Brandt et al. 2014). The majority of Southern Ocean samples also come from less than $500 \mathrm{~m}$ in depth, even though $90 \%$ of the region is deeper than $1000 \mathrm{~m}$ (Griffiths 2010). To address some of these gaps, the British Antarctic Survey led project "Biodiversity dynamics: phylogeography, evolution, and 
radiation of life (BIOPEARL)" organized two large biological research cruises aboard the RRS James Clark Ross to the Scotia Sea (BIOPEARL I - JR144) and the Amundsen Sea (BIOPEARL II - JR179) in the austral summer of 2006 and 2008 respectively. The collections from the Amundsen Sea and Pine Island Bay area on JR179 were the first benthic samples to be collected in this region.

Together, the BIOPEARL samples represent one of the largest single collections of benthic fauna in the Antarctic undertaken with comparative sampling methodologies, and in this study, we focus on results from the identification of the polychaetes, annelid worms that dominate Antarctic marine macrofauna (e.g. Gambi et al. 1997; Hilbig et al. 2007; Glover et al. 2008). We compare patterns in polychaete assemblage composition and biodiversity across the Scotia and Amundsen Seas and evaluate the prevailing hypotheses of high endemism, extended eurybathy and biodiversity hotspots in Southern Ocean benthos. Finally, we make our raw data and vouchered samples available for future study (see supplementary information).

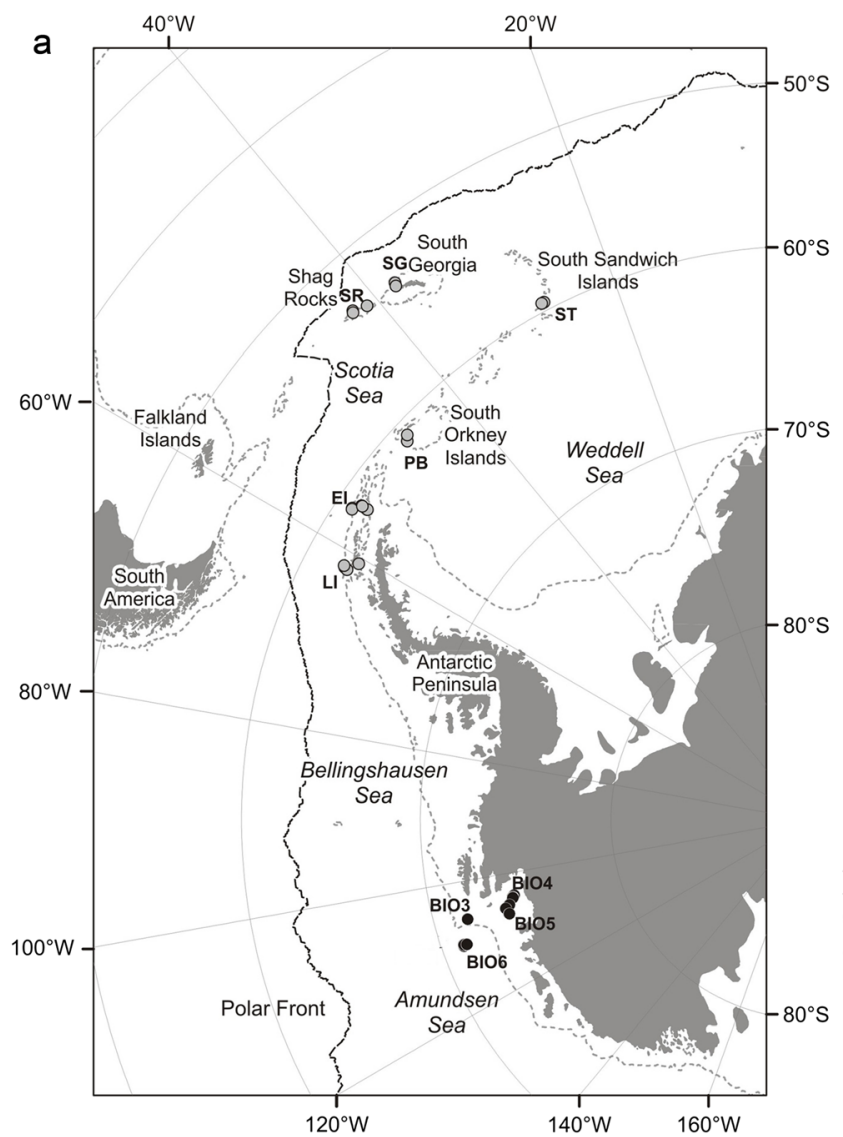

Fig. 1 Sampling sites and background environmental information. (a) Map of sampling sites during the cruises BIOPEARL I - JR144 to Scotia Sea (white circles) and BIOPEARL II - JR179 to the Amundsen Sea (black circles). (b) Productivity estimated by chlorophyll a concentration in the Amundsen Sea (BIOPEARL II) for austral summer

\section{Study sites and methodology}

\section{Scotia Sea}

The Scotia Sea (Fig. 1a) is bounded by the islands of the Scotia Arc to the northeast, the Weddell Sea to the south and the tip of the west Antarctic Peninsula to the west. It combines archipelagos, seamounts, and submerged banks separated by relatively young (30 Ma) deep seafloor (Barker 2001). Islands and shelves of the Scotia Sea differ greatly in characteristics such as age, geological origin, size, remoteness, ascent and expanse of their shelves and position relative to Polar Front (see Table 1 for details, see Thomson 2004). In terms of oceanography, the major current system that impacts the Scotia Sea shelves is the Antarctic Circumpolar Current (ACC) driven by westerly winds. The archipelagos of the Scotia Arc are thought to provide a link between South America and the Antarctic Peninsula and it has been considered a boundary for different biogeographical provinces (Dell 1972).

During the Austral summer of 2006, the RRS James Clark Ross collected biological samples over extensive area

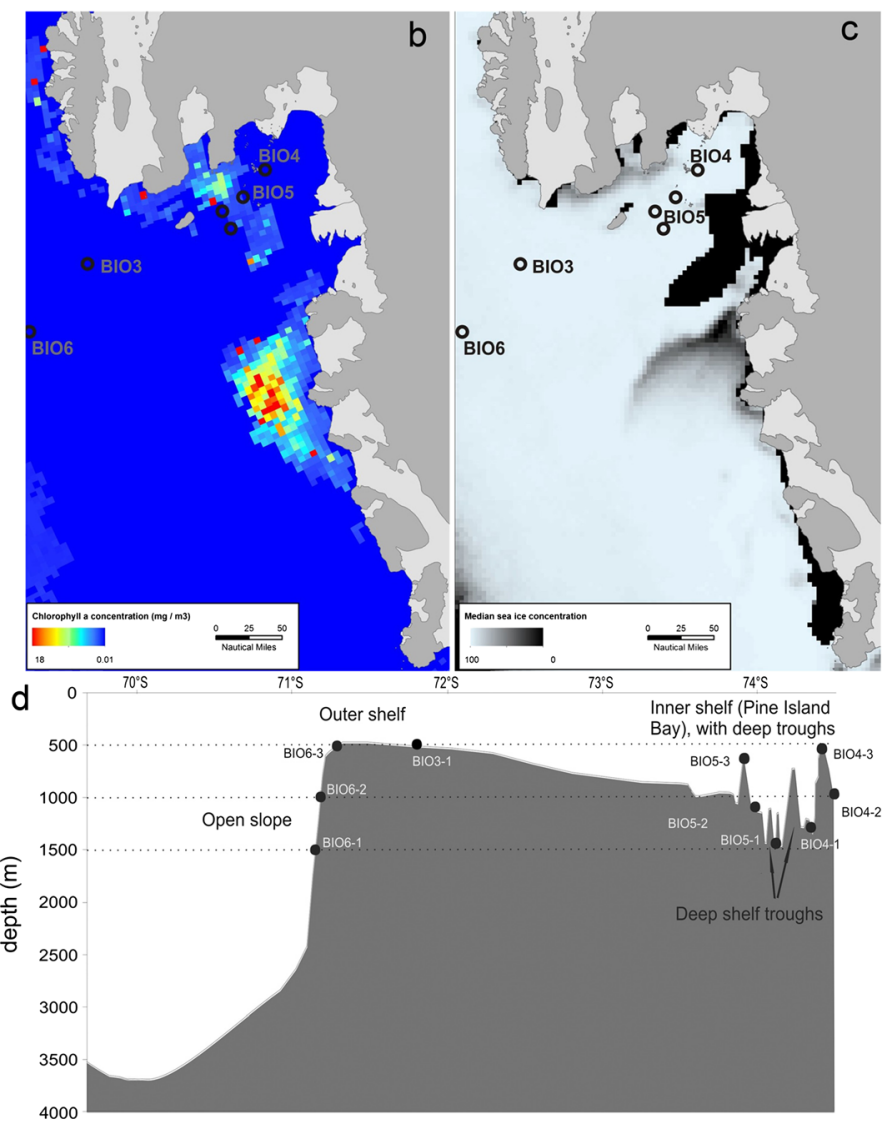

2007-8 (source: http://oceancolor.gsfc.nasa.gov/cgi/l3) (c) position of polynyas in the Amundsen Sea in relation to sampling site of BIOPEAR II. (d) Depth cross-section of shelf and slope in the Amundsen Sea, showing deep-trough sites on inner shelf (Pine Island Bay) and outer shelf/slope 
Table 1 List of BIOPEARL sampling stations including depth, position, and brief site descriptions

\begin{tabular}{|c|c|c|c|c|c|c|}
\hline $\begin{array}{l}\text { Sea } \\
\text { (Cruise) }\end{array}$ & Site & Sample & $\begin{array}{l}\text { Depth (m) } \\
\text { EBS (on } \\
\text { bottom) }\end{array}$ & $\begin{array}{l}\text { Latitude } \\
\text { (EBS on } \\
\text { bottom) }\end{array}$ & $\begin{array}{l}\text { Longitude } \\
\text { (EBS on } \\
\text { bottom) }\end{array}$ & $\begin{array}{l}\text { General environmental description } \\
\text { of the site }\end{array}$ \\
\hline
\end{tabular}

\begin{tabular}{|c|c|c|c|c|c|}
\hline \multicolumn{6}{|l|}{ Scotia Sea (BIOPEARL I - JR144) } \\
\hline \multirow[t]{5}{*}{ South Georgia (SG) } & SG-EBS-1 & 1508 & -53.55144 & -37.90777 & \multirow{5}{*}{$\begin{array}{l}\text { SG: Geologically old (continental } \\
\text { fragment); with extensive shelf area; } \\
\text { dominated by advective flow of the } \\
\text { ACC; lack (rarity) of ice cover; sea } \\
\text { temperatures reaching }>4 \mathrm{C}^{\circ} \text {. }\end{array}$} \\
\hline & SG-EBS-5 & 316 & -53.78975 & -37.97755 & \\
\hline & SG-EBS-2 & 1012 & -53.57651 & -37.88375 & \\
\hline & SG-EBS-3 & 503 & -53.59745 & -37.90212 & \\
\hline & SG-EBS-4 & 222 & -53.61109 & -37.88388 & \\
\hline \multirow[t]{3}{*}{ Shag Rocks (SR) } & SR-EBS-6 & 1499 & -53.25323 & -42.1439 & \multirow{3}{*}{$\begin{array}{l}\text { SR: Geologically old (continental } \\
\text { fragment); dominated by advective } \\
\text { flow of the ACC; lack (rarity) of ice } \\
\text { cover; sea temperatures can reach up to } \\
4 \mathrm{C}^{\circ} \text {. }\end{array}$} \\
\hline & SR-EBS-5 & 502 & -53.32117 & -42.23422 & \\
\hline & SR-EBS-4 & 206 & -53.6281 & -40.90741 & \\
\hline \multirow[t]{5}{*}{ Southern Thule (ST) } & ST-EBS-1 & 1569 & -59.52289 & -27.46355 & \multirow{5}{*}{$\begin{array}{l}\text { ST: Geologically young }(<5 \mathrm{Ma}) \\
\text { volcanic in origin; tectonically active; } \\
\text { with narrow shelf and steep ascent; } \\
\text { highly isolated by both geography and } \\
\text { bathymetry. }\end{array}$} \\
\hline & ST-EBS-3b & 507 & -59.48003 & -27.28818 & \\
\hline & ST-EBS-2 & 1008 & -59.50717 & -27.30057 & \\
\hline & ST-EBS-3 & 545 & -59.48079 & -27.27717 & \\
\hline & ST-EBS-4 & 305 & -59.47038 & -27.27562 & \\
\hline \multirow[t]{4}{*}{ Powell Basin (PB) } & PB-EBS-4 & 211 & -60.82165 & -46.48529 & \multirow{4}{*}{$\begin{array}{l}\text { PB: Geologically old (continental } \\
\text { microfragment); seasonally highly } \\
\text { productive; anomalously cold due to } \\
\text { influence of Weddell Sea gyre; shelf } \\
\text { area } \sim 42,400 \mathrm{~km}^{2} \text {, nearly } 400 \mathrm{~km} \\
\text { from the next nearest shelf north of } \\
\text { Antarctic Peninsula. }\end{array}$} \\
\hline & PB-EBS-3 & 504 & -60.99021 & -46.83181 & \\
\hline & PB-EBS-2 & 987 & -61.03489 & -46.86674 & \\
\hline & PB-EBS-1 & 1636 & -61.03592 & -46.95587 & \\
\hline \multirow[t]{5}{*}{ Elephant Island (EI) } & EI-EBS-5 & 543 & -60.9695 & -55.96435 & \multirow{5}{*}{$\begin{array}{l}\text { EI: Geologically old (continental } \\
\text { fragment); with extensive shelf area; } \\
\text { with extensive seasonal sea cover. }\end{array}$} \\
\hline & EI-EBS-3 & 495 & -61.38541 & -55.19338 & \\
\hline & EI-EBS-4 & 204 & -61.33542 & -55.20366 & \\
\hline & EI-EBS-2 & 999 & -61.5727 & -55.24043 & \\
\hline & EI-EBS-1 & 1482 & -61.61095 & -55.21554 & \\
\hline \multirow{4}{*}{$\begin{array}{l}\text { Livingstone Island } \\
\text { (LI) }\end{array}$} & LI-EBS-4 & 191 & -62.52529 & -61.83044 & \multirow{4}{*}{$\begin{array}{l}\text { LI: Geologically old (continental } \\
\text { fragment); with extensive shelf area; } \\
\text { with extensive seasonal sea cover. }\end{array}$} \\
\hline & LI-EBS-3 & 557 & -62.3956 & -61.76972 & \\
\hline & LI-EBS-2 & 878 & -62.33526 & -61.65266 & \\
\hline & LI-EBS-1 & 1455 & -62.27685 & -61.59502 & \\
\hline \multicolumn{6}{|l|}{$\begin{array}{l}\text { Amundsen Sea } \\
\text { (BIOPEARL II - JR179) }\end{array}$} \\
\hline \multirow{4}{*}{$\begin{array}{l}\text { BIO4-deep inner shelf } \\
\text { (trough site) }\end{array}$} & BIO4-EBS-1B & 1468 & -74.35689 & -104.75592 & \multirow{7}{*}{$\begin{array}{l}\text { BIO4: Deep trough of inner shelf in Pine } \\
\text { Island Bay extending to depths } \\
\text { of over } 1500 \mathrm{~m} \text {, lying under influence } \\
\text { of productivity of Pine Island polynya } \\
\text { and proximity of PIB glaciers, with } \\
\text { intrusion of Circumpolar Deep Water; } \\
\text { muddy habitat }\end{array}$} \\
\hline & BIO4-EBS-1A & 1414 & -74.35908 & -104.74936 & \\
\hline & BIO4-EBS-2B & $\sim 1000$ & -74.48722 & -104.3347 & \\
\hline & BIO4-EBS-2A & 1169 & -74.48248 & -104.3461 & \\
\hline \multirow{3}{*}{$\begin{array}{l}\text { BIO4-inner shelf } \\
\text { (trough site) }\end{array}$} & BIO4-EBS-3F & 523 & -74.38964 & -104.7645 & \\
\hline & BIO4-EBS-3E & 516 & -74.39564 & -104.75862 & \\
\hline & BIO4-EBS-3D & 506 & -74.39051 & -104.76792 & \\
\hline
\end{tabular}

$-74.402 \quad-104.61633$

$-74.39818 \quad-104.63342$

$\begin{array}{llrrr}\text { BIO5-deep inner shelf } & \text { BIO5-EBS-2B } & 1126 & -73.88595 & -106.29571\end{array}$

$\begin{array}{lllll}\text { (trough site) } & \text { BIO5-EBS-2A } & 1052 & -73.87964 & -106.31846\end{array}$

$-74.1175 \quad-105.84145$

$\begin{array}{rrrrr} & \text { BIO5-EBS-1A } & 1472 & -74.11757 & -105.84202 \\ \text { BIO5-inner shelf } & \text { BIO5-EBS-3E } & 536 & -73.98286 & -107.40483\end{array}$

$\begin{array}{lllll}\text { (trough site) } & \text { BIO5-EBS-3D } & 550 & -73.97782 & -107.41677\end{array}$

$\begin{array}{ll}-73.98102 & -107.39772\end{array}$

$-73.97655 \quad-107.41105$

$-73.97161 \quad-107.42369$

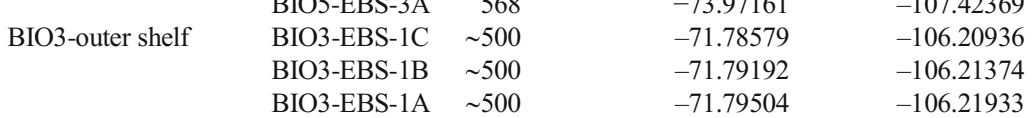

$\begin{array}{lllll}\text { BIO6-open slope } & \text { BIO6-EBS-1B } & 1461 & -71.16223 & -110.07273 \\ & \text { BIO6-EBS-1A } & 1457 & -71.15723 & -110.07112 \\ & \text { BIO6-EBS-2B } & 1005 & -71.17799 & -109.88426 \\ & \text { BIO6-EBS-2A } & 1020 & -71.17495 & -109.85415\end{array}$

BIO5: Deep trough extending to depths of over $1500 \mathrm{~m}$ lying under influence of productivity of Pine Island polynya and proximity of PIB glaciers with intrusion of Circumpolar Deep Water; muddy habitat.

BIO3: Outer shelf; around $400 \mathrm{~km}$ distance from PIB; smooth topography; lower productivity in comparison to PIB; extensive ice cover; muddy habitat.

BIO6: Outer shelf and open slope; around $400 \mathrm{~km}$ distance from PIB; lower productivity in comparison to PIB; extensive ice cover; muddy habitat 
Table 1 (continued)

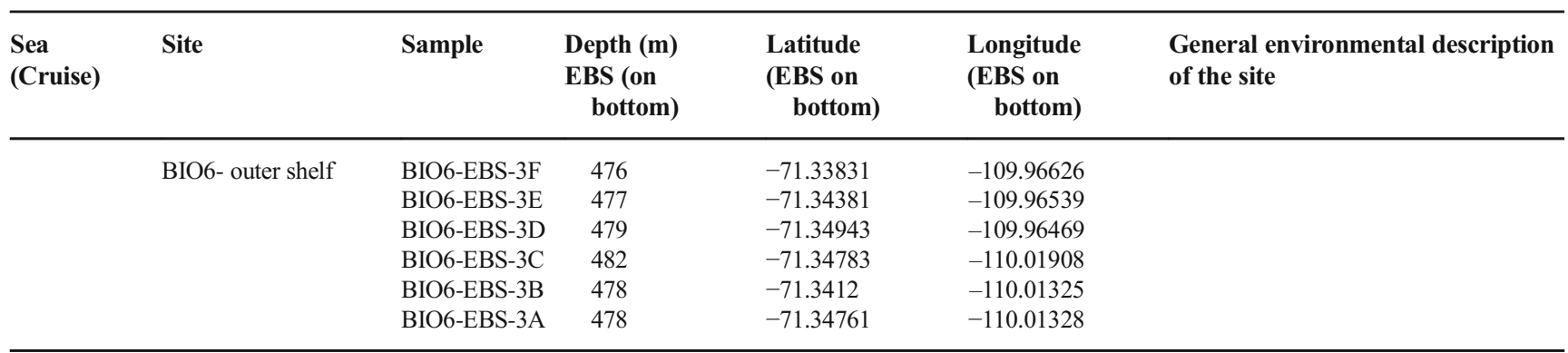

covering seven locations [Falkland Trough (FT), Livingston Island (LI), Elephant Island (EI), Powell Basin (PB), Southern Thule (ST), South Georgia (SG) and Shag Rocks (SR)] vertical depth transects with sampling stations at $200 \mathrm{~m}, 500 \mathrm{~m}$, $1000 \mathrm{~m}$, and $1500 \mathrm{~m}$ were designed with a single EBS deployment per depth. At South Georgia, an additional $300 \mathrm{~m}$ station was collected. In total 26 samples were collected from the Scotia Sea (see Table 1 for details and descriptions of these sites).

\section{Amundsen Sea}

The Amundsen Sea (Fig. 1) forms the main sea of the western Antarctic, located between the Bellingshausen Sea and the Ross Sea. Because of its extreme isolation and almost perennial sea-ice cover, it is almost never sampled for marine benthic life, although it has recently become a focus of major geophysical interest with the proposition of rapid melting of the Pine Island Glacier that feeds into Pine Island Bay, the major embayment of the Amundsen Sea (e.g. Rignot and Jacobs 2002; Thomas et al. 2004; Jacobs et al. 2011; Smith et al. 2016). Pine Island Glacier and the nearby Thwaites Glacier are two of the largest Antarctic glaciers and together with the ice sheets that feed into the Amundsen Sea are likely to have a dramatic influence on the local biology. The margins of Pine Island and Thwaites glaciers produce deep-keeled icebergs that can scour to depths of $500 \mathrm{~m}$ (Evans et al. 2006), and over geological time the region has been subject to intense glaciation and deglaciation events. As a result of these dynamic past and present ice conditions, the inner shelf of Pine Island Bay is topographically complex - a mosaic of cavities, drainage channels, valleys, and furrows. Many of these depressions exceed $500 \mathrm{~m}$ depth, with some troughs extending beyond $1500 \mathrm{~m}$ in depth (Lowe and Anderson 2002) (Fig. 1d). Toward the outer shelf the topography becomes smoother and the water depth shallower (350-450 m).

In terms of water masses, the central Amundsen Sea represents an area for exchange between Pacific and Atlantic oceans (Grotov et al. 1998) driven by the flow of the ACC. The lack of shelf and bottom water formation means that water temperatures are lower than in the adjacent Bellingshausen Sea, but warmer than Ross Sea waters (Thoma et al. 2008). A westward coastal current dominates the current system of the Amundsen Sea shelf and slope. The coastal current is suggested to derive from the Antarctic Polar Slope Current, transporting cold waters from the Weddell into the Amundsen Sea (Grotov et al. 1998). At the same time, the continental shelf of the Amundsen Sea is also periodically and unpredictably flooded by warmer Circumpolar Deep Water (Thoma et al. 2008). In terms of productivity (Fig. 1b) the inner shelf of the Amundsen Sea lies under influence of two highly productive polynyas - Pine Island Bay Polynya and Amundsen Sea Polynya (Arrigo et al. 2012; Yager et al. 2012) with further nutrients supplied by melting glaciers (Alderkamp et al. 2012).

During the Austral summer of 2008, the RRS James Clark Ross collected extensive biological samples within Pine Island Bay for the first time, with sea-ice much reduced compared to normal conditions. The cruise sampled four different sites: BIO4 and BIO5 (an inner shelf area of complex and often deep topography near the Pine Island Glacier) and BIO3 and BIO6 (outer, open shelf and slope). Three different depths $(500 \mathrm{~m}$, $1000 \mathrm{~m}$, and $1500 \mathrm{~m}$ ) were sampled at the BIO4, 5, and 6 sites, with multiple EBS deployments, ranging from 2 to 6 . At $\mathrm{BIO} 3$ sites only the $500 \mathrm{~m}$ horizon was sampled, with 3 deployments. In total, 32 samples were collected from the Amundsen Sea (see Table 1 for details).

\section{Field sampling protocol}

All benthic samples were collected with epibenthic sledge (EBS) (Brenke 2005) during both cruises. Briefly, the EBS is a towed metal box consisting of two sampling nets and cod ends, the "epi-net" that is towed just above the seafloor, and the "supra-net" which is just above the epinet, each with an opening of $100-\mathrm{cm}$ width and $33-\mathrm{cm}$ height. The mesh size of the nets is $500 \mu \mathrm{m}$ and both nets 
end up in a cod end with a mesh size of $300 \mu \mathrm{m}$. The typical deployment procedure is to lower the device with the ship moving slowly ahead, once on the seafloor the EBS is hauled across the seabed at 1 knot for $10 \mathrm{~min}$. The action of landing the EBS on the seafloor automatically opens doors to the nets, which close on recovery so limiting the sample to benthic and epibenthic fauna only. Disturbance of the seabed at the front of the device results in small fauna being entrained in the nets and captured in the cod ends. The main advantage of the EBS over coring devices is that large amounts of specimens are collected without significant quantities of sediment. However, the area sampled by this device cannot be established with great accuracy, making it a semi-quantitative sampler at best.

On the BIOPEARL I cruise, all samples were fixed immediately in $96 \%$ ethanol and stored at $-20{ }^{\circ} \mathrm{C}$ (for DNA and morphology studies). On the BIOPEARL II cruise, a proportion of samples were fixed in 10\% formalin (for morphology study only), with the formalin samples later being transferred to $80 \%$ ethanol, while some samples were taken for live sorting, photography and DNA fixation and preservation, following similar protocols to Glover et al. (2016) or simply bulk preserved in $96 \%$ ethanol and stored at $-20{ }^{\circ} \mathrm{C}$. In the laboratory, all samples were sieved again on $300 \mu \mathrm{m}$ sieves to remove residual mud before sorting and identification.

\section{Laboratory sorting and identification}

The large number of macrofaunal individuals recovered (59,500 from the BIOPEARL I and 205,429 from BIOPEARL II samples) resulted in a major sorting effort that took approximately four years to complete to class or family level. The macrofaunal sorting (including macrofauna-sized meiofauna such as ostracods and copepods) was completed in a collaborative way involving different institutes and different sorters (see acknowledgements). A total of around 19,500 polychaete specimens were gathered at the Natural History Museum Deep-Sea Systematics and Ecology Group research lab for final species-level identification. Other macrofaunal groups were also targeted during the BIOPEARL projects, with data for isopods (Kaiser et al. 2009) and tanaids (Pabis et al. 2015a) crustaceans already published. Molluscs were also analysed (Moreau et al. 2013), but their biodiversity analyses are as yet unpublished (Linse, personal communication). The main taxonomist was first author (LN), supervised by $\mathrm{AG}$, and two master students (see acknowledgements) supervised by $\mathrm{LN}$ and $\mathrm{AG}$ also contributed their unpublished data. No large-scale funding was made available for any of the postcruise sorting and identification, the entire operation was completed on small grants-of-opportunity and by volunteers, which also contributed to the length of time needed for completion of the sorting.
A specimen database was created and Leica MZ6 and DM5000 stereo and compound microscopes were used to identify polychaete specimens. Where specimens were fragmented, only head-bearing fragments were considered (counted and identified), which is a standard practice. Named species identification (where possible) was carried out using identification keys and original literature. Where a named species identification could not be obtained, the specimen was recorded as a morpho-species in a genus (e.g. Tharyx sp. A) or family (e.g. Ampharetidae sp. A). For every species found, a voucher specimen was erected. Images of these specimens were captured using a Zeiss V.20 and AxioCam HRc, and a Leica DFC 480 dedicated camera system connected to the DM5000. A voucher worksheet was created for a majority of such specimens, including a brief diagnostic description of the species and photographs. Voucher worksheets for some abundant species are being made available on the NHM Data Portal (http:// data.nhm.ac.uk/). We are aware that taxonomic and identification literature and faunal lists available for the Southern Ocean polychaete fauna are outdated and in need of an update. Some recent taxonomic studies targeting Southern Ocean polychaete taxa became available only after the morphological identification work for this study was completed and entered into the database (e.g López 2011; Schüller and Jirkov 2013; Blake 2015, 2016). We have made our data and vouchers available for future study and revision in the light of these changes, which have no impact on the biodiversity comparisons in the results of this study. The identification of specimens to morphospecies was time-consuming due to the large number of specimens involved. Additionally, many specimens were damaged and fragmented (particularly those bulk-preserved directly in frozen $96 \%$ ethanol) sometimes preventing a reliable morphological examination. A separate study of DNA sequences from a selected sub-sample of BIOPEARL material was conducted, published separately (Brasier et al. 2016) (see further comments in discussion).

\section{Data analysis}

Data were assembled into a Microsoft Excel database and the final species list was converted into a DarwinCore file for upload as Supplementary Information and to the NHM Data Portal including vouchered specimen records. For consistency, a large number ( 2500) of polynoid juveniles (see Neal et al. 2014 for details) and undeterminable specimens were removed from the analyses, resulting in the final dataset of 16,991 specimens.

Community analysis The matrices of family level and species level data were constructed in MS Excel and the 
subsequent analyses were carried out with the software PRIMER W v. 6. 1. 6 (Clarke and Gorley 2006). First, the efficiency of the gear was analysed using the species level data. With its two nets (the epinet and the supranet), the EBS was originally constructed to sample the epibenthos and suprabenthos separately (Brenke 2005). However, a one way $\operatorname{ANOSIM}(R=0.13, P=0.04)$ suggested that the two net samples were pseudo-replicates and were therefore combined and treated as one sample. Sampling with the EBS is only semi-quantitative (at best) and at Scotia Sea sites only single deployments per site were taken, while in the Amundsen Sea between two to six deployments were taken at each site (Table 1), leading to different numbers collected from each sea-11,660 from the Amundsen Sea, but only 5331 from the Scotia Sea. Given variation in numbers collected, the most conservative presence-absence data transformation was used to examine polychaete community patterns between two seas, while 4 th root data transformation, which takes a degree of abundance into account, was used to examine similarity of the fauna within each sea. The similarity analysis was carried out using calculation of Bray-Curtis index and visualization of results with nMDS plots (100 restarts).

As part of the data exploration, the data were first analysed with all samples separated (results not shown for clarity). The samples from the shelf depths (200, 300 , and/or $500 \mathrm{~m}$ ) in each sea were more similar to each other than to deeper samples from the same site. Therefore, in a secondary analysis (results shown), the samples were pooled per depth. In the case of Scotia Sea the samples from shelf depth were pooled as shelf $(200,300$, and $500 \mathrm{~m})$. Some samples collected from Scotia Sea deep sites suffered from low number of individuals in comparison to other sampled sites, not to other macrofaunal groups (see Table 4 for details) and were, therefore, pooled as slope (1000 and $1500 \mathrm{~m})$. In the Amundsen Sea, the $500 \mathrm{~m}$ horizon was considered a shelf depth, consistently with the Scotia Sea. The samples from $1000 \mathrm{~m}$ and $1500 \mathrm{~m}$ deep trough sites on the inner shelf were considered a deep shelf, while the same depth horizons from open slope were considered slope depth, again consistently with the Scotia Sea. However, the greater number of individuals collected at deeper sites in the Amundsen Sea compared to Scotia Sea enabled us to keep depth horizons of $1000 \mathrm{~m}$ and $1500 \mathrm{~m}$ separated. The statistical significance of the obtained groupings was tested using one-way ANOSIM with either location (Amundsen versus Scotia Sea) or depth (shelf, deep shelf, and slope) as a factor. SIMPER analysis was used to identify species responsible for the similarity within and between obtained clusters.

Analysis of species diversity The matrices of species level data were constructed in MS Excel and the subsequent analyses were carried out with the software ESTIMATE S (Colwell 2009). First, species accumulation curves were constructed to assess the completeness of the sampling effort. The curves were constructed for three different scenarios: 1) data from Amundsen Sea and Scotia Sea combined, 2) data from each sea kept separately (in accordance with clusters identified by nMDS analysis), and 3) data pooled per depth into "shelf" and "slope" of each sea (in accordance with clusters as identified by nMDS analysis and explained above). The concept of species diversity includes both species richness (the actual number of species) and the abundance. Local diversity was assessed by using the rarefaction approach (Sanders 1968) conducted on pooled samples (BIOPEARL II data) and data pooled into "shelf" and "slope" (200, 300, and $500 \mathrm{~m}=$ shelf; $1000 \mathrm{~m}$ and $1500 \mathrm{~m}$ = slope for BIOPEARL I data) to study species diversity patterns independent of sample size, although rarefaction is influenced by dominance (Gage and Tyler 1991; Gage and May 1993). The decision to pool data was guided by the results from nMDS analysis and the fact that samples from the Scotia Sea were very "patchy", and both seas differed greatly in a number of specimens collected. To supplement this approach, an individual based non-parametric species estimator of total species richness Chaol was also calculated (Chao 1984). The choice of individual based rather than samples based estimator was given by the nature of our data. At some sites only one or two samples were collected, with six samples being the highest number collected, such numbers are impossible or very low for any meaningful statistical analysis.

\section{Results}

\section{Sampling intensity}

A total of 16,991 polychaete specimens were examined from an approximate total of 19,500 polychaetes in the BIOPEARL macrofaunal sorting effort. From this, 307 morphospecies in 42 families were determined based on morphology. About 25\% were identified to a named species while the remaining were designated as "cf." or morphospecies only, owing to poor specimen condition, lack of appropriate taxonomic references. In terms of sampling intensity, the pooled data show some evidence that the sites are approaching asymptote in terms of species numbers with the Amundsen Sea more exhaustively sampled than the Scotia Sea. However, the number of species is still increasing and the asymptote has not been reached, particularly in deep shelf and slope depths of both seas (Fig. 2b), from which lower numbers of individuals were recovered. 


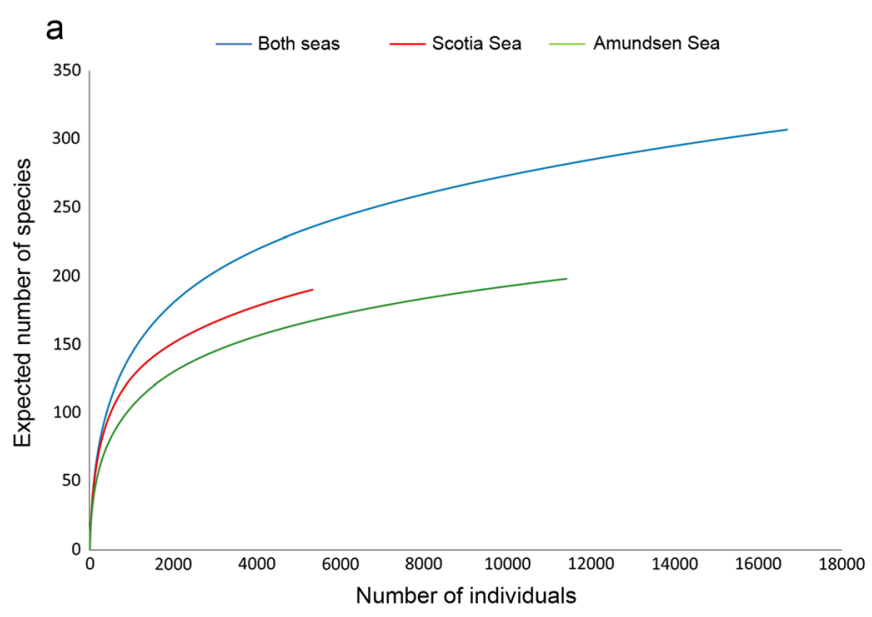

Fig. 2 Sampling effort for polychaete diversity assessed by rarefaction curves. (a) combined data for both sampled seas and for Scotia and Amundsen Sea separated and (b) separated by shelf and slope depths from each sea (with Amundsen Sea inner shelf and slope sites separated

\section{Community analysis}

Faunal similarity analysis between Scotia and Amundsen seas The analysis of species level data (nMDS plot, presenceabsence transformation (Fig. 3a) carried out on pooled samples clearly revealed two main clusters, which correspond to the two seas, Scotia and Amundsen Sea (ANOSIM: factor Location: $R=0.638, P=0.1 \%$ ), revealing a homogeneity (similarity) of Amundsen Sea data (points lie closely together on nMDS) and heterogeneity within Scotia Sea cluster (points more widely spread). SIMPER analysis of species data revealed average dissimilarity between two seas as high as $76.73 \%$. At family level, the Scotia Sea was dominated by Syllidae and Amundsen Sea by Polynoidae. Further inspection of the nMDS plot for species-level data suggested that within each sea there was a clustering related to depth. Each dataset was, therefore, analysed separately to further investigate this pattern using species level 4th root transformed data.

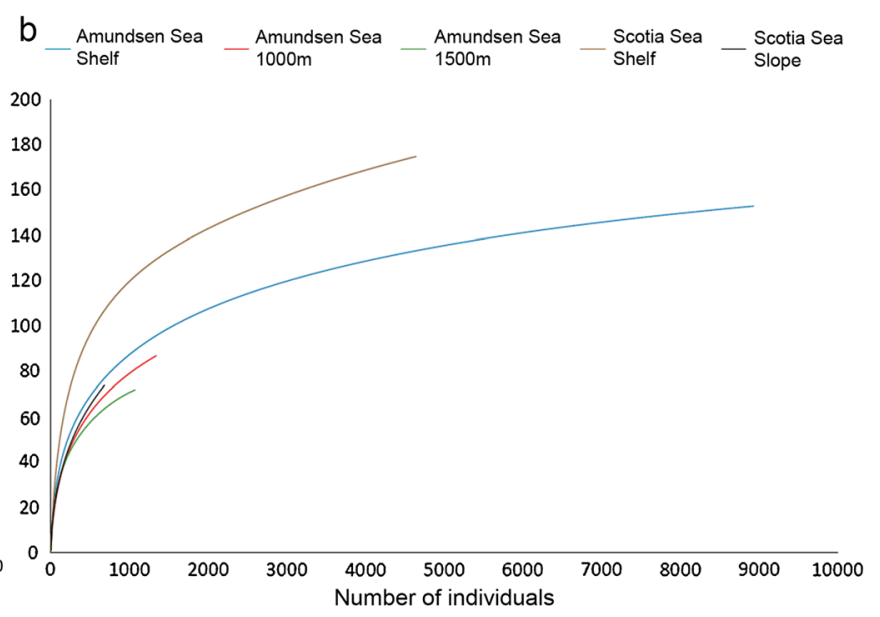

into $1000 \mathrm{~m}$ and $1500 \mathrm{~m}$ categories). The results suggest that deeper inner shelf site of the Amundsen Sea (1000 m and $1500 \mathrm{~m}$ ) and slope depths in both seas remain undersampled, while shelf sites are relatively well sampled

It was noted that when analysed based on family data alone, no significant clustering between seas was observed (results not shown).

Faunal similarity within Amundsen Sea Further investigation of the pattern of faunal similarity showed that depth (rather than geographical proximity of the sites) is the main factor affecting faunal similarities. The nMDS analysis of Amundsen Sea data (Fig. 3b) clearly separated the shelf data from the deep-shelf/slope data (ANOSIM: factor Depth: $R=0.803, P=0.1 \%$ ), and the two-inner shelf trough stations BIO4 and BIO5 are more similar to each other at each depth horizon, while outer shelf stations BIO3 and BIO6 were also more similar to each other once the influence of depth was removed (Fig. 3b). Species that drive the similarity within each cluster were identified by SIMPER analysis (Table 2). Interestingly, three species were dominant in both shelf and deep-shelf/slope clusters: Glycera kerguelensis McIntosh,

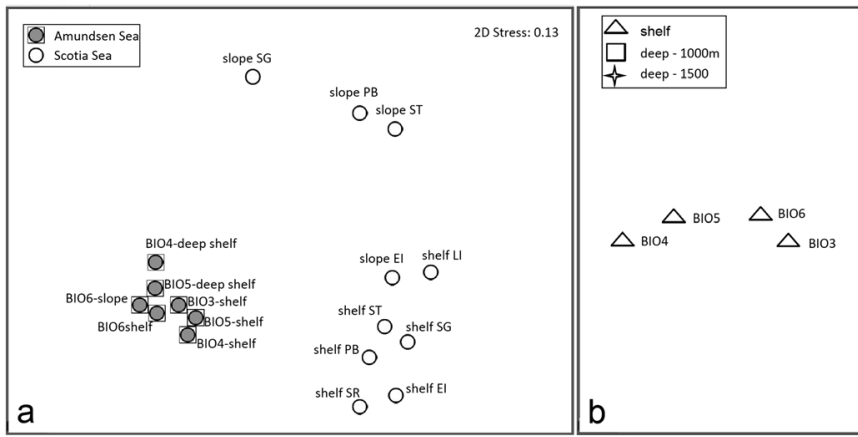

Fig. 3 Community analysis, non-metric multidimensional scaling (nMDS) representation of faunal similarity at species level based on (a) Combined dataset for both seas, nMDS representation of similarity of Scotia and Amundsen Sea polychaete species by sites (ANOSIM: factor Location: $R=0.638, P=0.1 \%$ ). All data presence/absence transformed. (b) nMDS analysis representation of similarity of Amundsen Sea

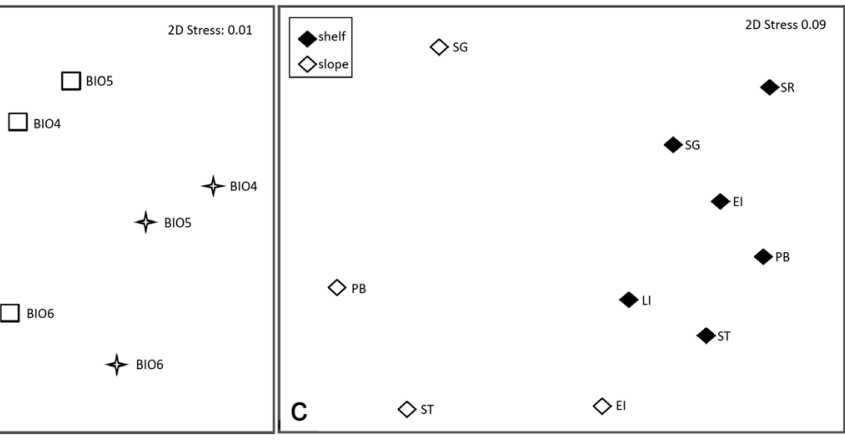

(BIOPEARL II) polychaete species (4th root transformed) abundance data. Depth is the main factor driving similarity (ANOSIM analysis for factor Depth: $R=0.803, P=0.1 \%$ ). (c) nMDS analysis representation of similarity of Scotia Sea (BIOPEARL I) polychaete species (4th root transformed) abundance data (ANOSIM: factor Depth: $R=0.734$, $P=0.5 \%)$ 
Table 2 SIMPER analyses of Amundsen Sea species data (4th root transformed) supporting structuring of fauna (top 5 species listed) their contribution toward the total abundance and functional (feeding) group

\begin{tabular}{|c|c|c|c|c|}
\hline Cluster & Family & Species/Morphospecies & $\begin{array}{l}\% \text { of total } \\
\text { abundance } \\
\text { (data 4th root } \\
\text { transformed) }\end{array}$ & Functional group \\
\hline
\end{tabular}

Shelf

(500 $\mathrm{m}$ depth horizon)

Average similarity: 52.13

\begin{tabular}{llll} 
Glyceridae & Glycera kerguelensis complex & 5.77 & predator, scavenger \\
Polynoidae & Harmothoe fuligineum & 5.2 & predator \\
Polynoidae & Austrolaenilla antarctica & 5.02 & predator \\
Hesionidae & Hesionidae sp. A & 4.12 & predator, scavenger \\
Fauveliopsidae & Laubieriopsis brevis & 3.59 & deposit feeder \\
Polynoidae & Austropolaria magnicirrata & 9.92 & predator \\
Glyceridae & Glycera kerguelensis complex & 8.78 & predator, scavenger \\
Polynoidae & Austrolaenilla antarctica & 8.33 & predator \\
Polynoidae & Macellicephala sp. A & 6.98 & predator \\
Hesionidae & Hesionidae sp. A & 6.63 & predator, scavenger \\
\hline
\end{tabular}

1885 complex, Austrolaenilla antarctica Bergström, 1916, and morphospecies Hesionidae sp. A. Polynoidae were the most abundant family, comprising ca. $30 \%$ of all polychaetes at Amundsen Sea and different Polynoidae species were driving the pattern of the depth zonation with Harmothoe fuligineum (Baird, 1865) dominating shelf depths, while Austropolaria magnicirrata Neal, Barnich, Wiklund \& Glover, 2012 and undescribed Macellicephala sp. A dominated deep-shelf and slope. (Table 2). Overall the Amundsen Sea data showed similarity of $54.27 \%$ according to SIMPER analysis. The shelf and deep-shelf/slope clusters had dissimilarity of $61.16 \%$, driven mainly by the following polychaete species: Austropolaria magniccirata Neal, Barnich, Wiklund \& Glover, 2012 and Harmothoe fuligineum (Baird, 1865) (both Polynoidae), undescribed accrocirrid Flabelligena sp. nov. A, Ophelina abranchiata Støp-Bowitz, 1948 and Laubieriopsis brevis (Hartman, 1967).

Faunal similarity within Scotia Sea The Scotia Sea species level data (Fig. 3c) showed much greater heterogeneity at a similarity of only $31.86 \%$ according to SIMPER analysis.
Depth was also the major factor structuring the polychaete assemblages, with shelf data separated from slope data (ANOSIM: factor Depth: $R=0.734, P=0.5 \%$ ). Besides the depth pattern, the Scotia Sea data were too heterogeneous to show any other patterns. The slope sites showed great dissimilarity not only from the shelves, but also from each other and could not be considered a cluster. This heterogeneity was likely due to undersampling (with only one replicate collected per depth) and was reduced by pooling the shelf depth sites (200 m, $300 \mathrm{~m}$, and $500 \mathrm{~m})$ as "shelf" and slope depth sites (1000 $\mathrm{m}$ and $1500 \mathrm{~m})$ as "slope". Shelves formed a loose cluster of average similarity of $30.79 \%$. Species diriving this similarity were identified by SIMPER analysis, with most contribtion from following species: Laonice weddellia Hartman, 1978, Sphaerodoropsis parva (Ehlers, 1913), Exogone minuscula Hartman, 1953, and two morphospecies Prosphaerosyllis sp. A and Chaetozone sp. H. (Table 3). The isolated Southern Thule did not represent an "outlier" in terms of species composition, suggesting ties to other shelves of Scotia Arc. Elephant Island and Livingstone Island, which lie close together and also represent a similar soft-sediment
Table 3 SIMPER analyses of Scotia Sea species data (4th root transformed) supporting clustering of fauna (top 5 species listed) their contribution toward the total abundance and functional (feeding) group

\begin{tabular}{|c|c|c|c|c|}
\hline Cluster & Family & $\begin{array}{l}\text { Species/ } \\
\text { Morphospecies }\end{array}$ & $\begin{array}{l}\% \text { of total abundance } \\
\text { (data } 4 \text { th root } \\
\text { transformed) }\end{array}$ & $\begin{array}{l}\text { Functional } \\
\text { group }\end{array}$ \\
\hline \multirow{2}{*}{$\begin{array}{l}\text { Shelf }(200,300 \text { and } \\
500 \mathrm{~m} \text { depth } \\
\text { horizons }\end{array}$} & Spionidae & Laonice weddellia & 7.69 & deposit feeder \\
\hline & Syllidae & Sphaerosyllis sp. 1 & 5.86 & predator \\
\hline \multirow[t]{3}{*}{$\begin{array}{l}\text { Average similarity: } \\
\quad 30.79\end{array}$} & Spaherodoridae & $\begin{array}{l}\text { Sphaerodoropsis } \\
\text { parva }\end{array}$ & 5.34 & deposit feeder? \\
\hline & Syllidae & Exogone minuscula & 3.6 & predator \\
\hline & Cirratulidae & Chaeozone sp. H & 3.1 & deposit feeder \\
\hline
\end{tabular}


habitat, were very dissimilar in polychaete fauna at shelf depth. Interestingly, the faunal dissimilarity was also previously reported for macrobenthos analysed from Agassiz trawls collected during BIOPEARL I expedition to Scotia Sea (Griffiths et al. 2008). Similarly, close-lying South Georgia and Shag Rocks, affected by similar environmental conditions were dissimilar in faunal composition.

In summary, three broad clusters were identified by nMDS: Amundsen Sea shelf, Amundsen Sea deep shelf/slope and Scotia Sea shelf, while Scotia Sea slope sites were too dissimilar from each other to consider them a cluster, as well as representing different assemblages from the shelves sites. The species that define these assemblages are summarized in Tables 2 and 3 and are illustrated in Fig. 4.

\section{Analysis of species diversity}

Analysis of 16,991 specimens led to identification of 307 species in 42 families based on morphology alone. From the Amundsen Sea 11,660 specimens yielded 202 species, while from Scotia Sea a much smaller number of 5331 specimens led to a similar number of 190 species. The species diversity as measured by several indices across wide range of sites is summarized in Table 2, and Figs. 2, 5-8. The results can be best described as fluctuating between different sites. Using the highest common number of individuals in order to incorporate all sites, we compared these at species richness ES (40) and higher, but less inclusive ES (600) (Table 4, Fig. 5-8). The analysis suggests that sites could be, relative to each other, classified as sites with "high" biodiversity where ES (40) > 25, "intermediate", where ES (40) was 15-22.5 and "low" where ES $(40)<15$ (see Table 4 for summary). The values of $95 \%$ CIs was used to determine the statistical significance of these results and guide the biodiversity classifications (see Table 4 for summary of CIs values). These results were strengthened at greater samples size of ES (600), but only nine sites could be evaluated.

In the Scotia Sea, only few locations clearly stood out in terms of the biodiversity pattern. The shelf of Powell Basin was a site of relatively "high" biodiversity with ES $(40)=25.45$, while the disturbed environment of Southern Thule was considered having "low" biodiversity with ES $(40)=12.46$ and 11.35 for shelf and slope respectively (see Table 4 for values of $95 \%$ CIs). The supplementary approach using Chao 1 to estimate a total species richness at each site, however, muted some of these results suggesting shelves of South Georgia, Shag Rocks, and even Southern Thule may potentially harbour as many species as Powell Basin (see Table 4 for mean values and 95\% CIs). The Amundsen Sea was more homogeneous in terms of the biodiversity patterns, with most locations falling into "intermediate" classification (Table 4). The deep inner shelf trough sites had a slightly depressed diversity in comparison to outer slope.

\section{Discussion}

\section{Large-scale patterns in polychaete assemblages}

Although restricted to a single taxonomic group - the polychaetes - our data represents one of the largest single identified collections of material from the Southern Ocean. As such, these data provide a useful opportunity to assess basic patterns in assemblage structure that may be driven by wide range of environmental variables. The most striking pattern is that the Amundsen and Scotia Sea support very different polychaete assemblages (Fig. 3a), in keeping with previous published data on isopods and tanaids (Kaiser et al. 2009; Pabis et al. 2015a). Although both seas were dominated at a functional level by mobile predatory worms, these were different at the family level, with Syllidae dominating the Scotia Sea and Polynoidae the Amundsen Sea.

Separate analysis of Amundsen and Scotia Seas sites show strong structuring by depth, which in general terms, has been a long-recognized factor structuring marine communities (e.g. Gage and Tyler 1991; Rex and Etter 2010). However, in the Southern Ocean, increased eurybathy in some invertebrate groups has been documented, at least when compared to temperate shelves (Brey et al. 1996), while polychaetes are generally considered to have a wide bathymetric distribution even in lower-latitude environments. Trends toward increased eurybathy in Southern Ocean have been interpreted as an adaptation to survival in deeper water during glacial maxima (Brey et al. 1996). While some polychaete species may show wide bathymetric distribution (Table 2), the data presented here show that depth is an important environmental factor that defines the polychaete assemblage composition. It is likely that current local environmental conditions may mask previously reported patterns such as extended eurybathy. Alternatively, from an evolutionary perspective, a strong faunal dissimilarity between shelf and slope fauna, such as reported here could suggest that species were more likely to survive the glacial periods in shelf refugias, rather than migrating into deeper waters. Barnes and Kuklinski (2010) showed a similar pattern in the Weddell Sea shelf bryozoans, which were more similar to fauna of other Antarctic shelves than to those on adjacent Weddell Sea slope.

In contrast to our findings, Montiel et al. (2005), Hilbig (2004) and Hilbig et al. (2006) showed wider depth ranges at species level for Magellanic and Southern Ocean (Weddell Sea) polychaetes. Brandt et al. (2009) analysed the bathymetric depth ranges at polychaete family level within $100 \mathrm{~m}$ depth bins, showing that most families were spread over several thousand meters, although, species-level data may be more appropriate to assess depth zonation. Kaiser et al. (2011) showed that many isopods in the Southern Ocean were restricted to slope depths with a possibility of the existence of a unique Southern Ocean slope fauna, Recently, tanaid data 
Fig. 4 Images of polychaete species driving similarity and dissimilarity of assemblages as identified by SIMPER analysis (see Tables 2 and 3). Images are of preserved specimens, but for some specimens live images were also available (inset, unless stated otherwise). All scale bars are $1000 \mu \mathrm{m}$, all scale bars refer to preserved specimens. (a) Glycera kerguelensis complex (live), (b) Hesionidae sp. A, (c)

Austrollaenila antarctica (live), (d) Harmothoe fuligineum, (e) juvenile Polynoidae, including juveniles of $A$. antarctica and H. fuligineum, (f) Macellicephala sp. A, (g) Austropolaria magnicirrata, (h) Laubieriopsis brevis, (i) Fllabeligena sp. A, (j) Ophelina abranchiata, (k) Laonice weddellia, (i) Sphaerosyllis sp. A, (m) Sphaerodoropsis pava, (n) Exogone minuscula, (o) Chaetozone sp. $\mathrm{H}$
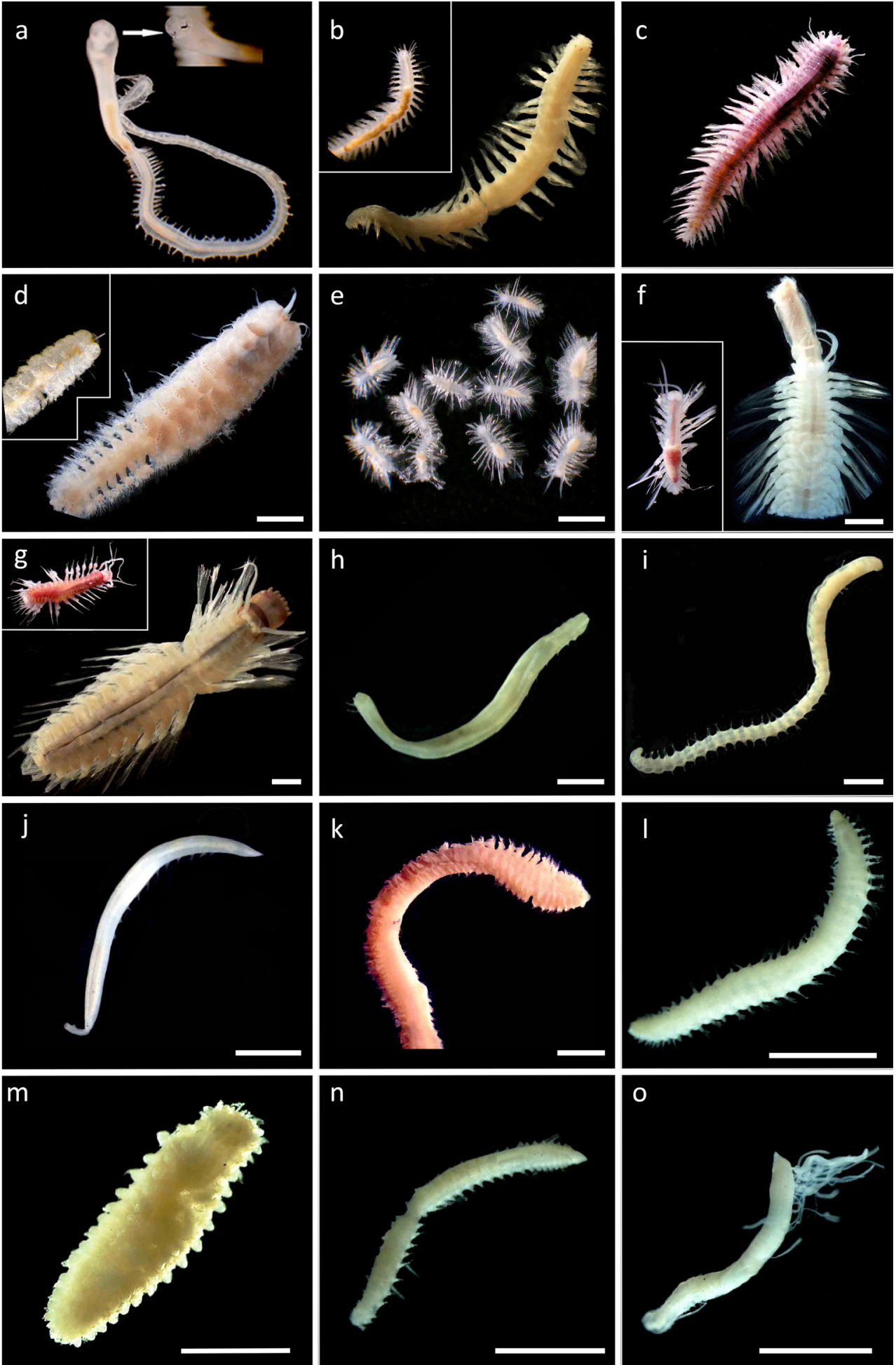

from the Ross Sea suggested the presence of a distinct slope fauna and strong structuring of tanaid assemblages by depth (Pabis et al. 2015b). The use of DNA techniques for taxonomic purposes has revealed the existence of cryptic species in Southern Ocean fauna (e.g. Barnes et al. 2011), including polychaetes (Schüller 2010; Neal et al. 2014; Brasier et al.
2016). Some eurybathic species may in fact be species complexes, with restricted depth ranges, contradicting the extended eurybathy hypothesis, as already demonstrated for Glycera kerguelenis McIntosh, 1885 (see Schüller 2010).

The Amundsen Sea. Detailed analysis of the Amundsen Sea sites shows a strong structuring by depth (Fig. 3b). In all depth 


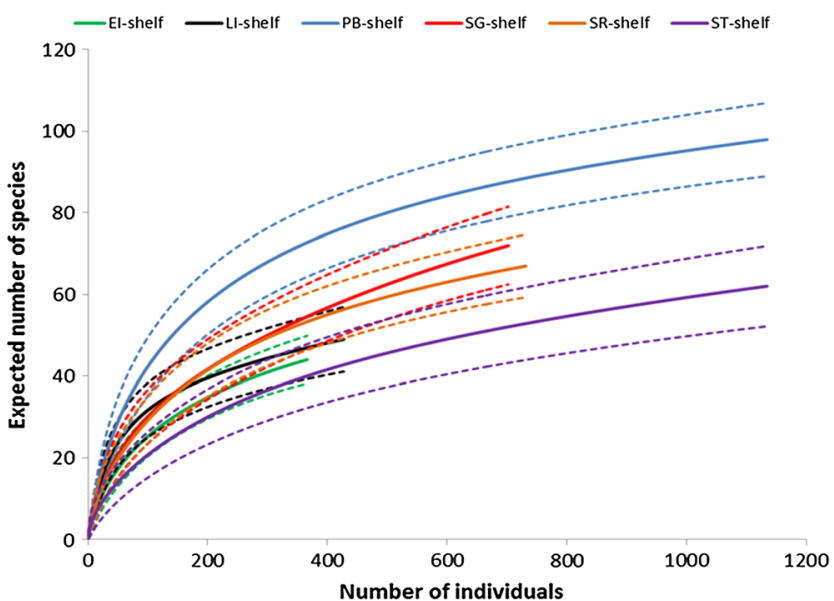

Fig. 5 Comparative polychaete diversity for sites on the Scotia Sea shelf, BIOPEARL I cruise. Sites are based on pooled data from several epibenthic sledge samples based on community analysis. Rarefaction curves represent mean value (full line) with $95 \%$ confidence intervals (dashed lines)

bins $(500 \mathrm{~m}, 1000 \mathrm{~m}, 1500 \mathrm{~m})$, the polychaete assemblages of inner shelf sites were more similar to those of the outer shelf/ slope separated by distance of $\sim 400 \mathrm{~km}$, rather than to assemblages from different depth horizons at the same sites. Only once the influence of depth is removed the geographical proximity becomes apparent with inner shelf troughs sites (BIO4 and $\mathrm{BIO5}$ ) being more similar to each other than the sites on the outer shelf/slope (BIO3 and BIO6). This pattern is consistent with findings for Amundsen Sea macrofauna (Linse et al. 2013) and macrobenthic molluscs (Linse, personal communication), suggesting that despite the similarity of deep inner shelf troughs with the adjacent continental slope, these do represent distinct communities.

Given such a strong pattern at different taxonomic levels and for different components of benthic fauna, it is likely that there is a common explanation. Thoma et al. (2008) showed that there is an intrusion of the Antarctic Circumpolar Deep Water onto the inner shelf of the Pine Island Bay. It has been

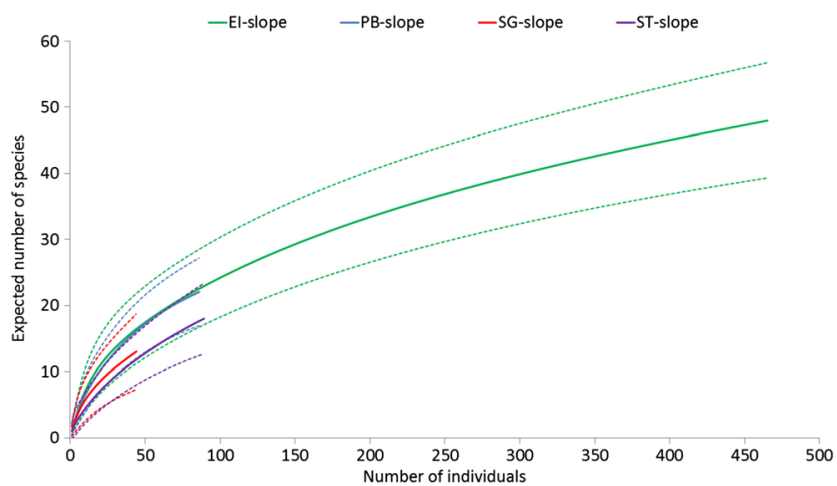

Fig. 6 Comparative polychaete diversity for sites on the Scotia Sea slope, BIOPEARL I cruise. Sites are based on pooled data from several epibenthic sledge samples based on community analysis. Rarefaction curves represent mean value (full line) with $95 \%$ confidence intervals (dashed lines)

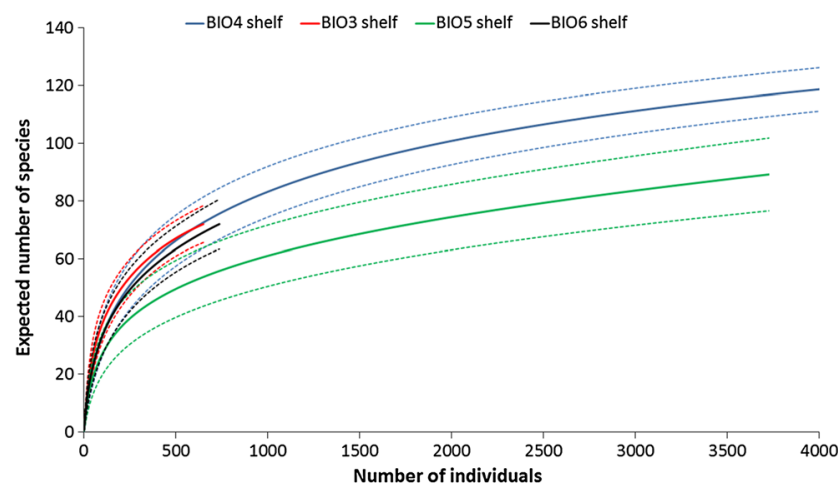

Fig. 7 Comparative polychaete diversity for sites on the Amundsen Sea Shelf, BIOPEARL II cruise. Sites are based on pooled data from several epibenthic sledge samples based on community analysis. Rarefaction curves represent mean value (full line) with $95 \%$ confidence intervals (dashed lines)

suggested that this intruding water mass connects the shelf troughs with deep water and may be supplying the Pine Island Bay troughs with deep-sea species (Kaiser et al. 2009; Riehl and Kaiser 2012; Linse et al. 2013). Riehl and Kaiser (2012) also showed genetic homogeneity of recentlydiscovered isopod Macrostylis roaldi across a broad bathymetric and geographic range within the sampled Amundsen Sea area. These observations together with data reported here, support the notion of high connectivity between the inner Amundsen Sea shelf troughs and the adjacent continental slope spanning distances of around $400 \mathrm{~km}$. Further support of deep-sea links can be seen in the taxonomic composition of polychaetes. Several abundant species of Polynoidae found on the shelf were representatives of the deep-sea subfamilies Macellicephaloidinae and particularly Macellicephalinae (Neal et al. 2012; Brasier et al. 2016). At $500 \mathrm{~m}$, our Amundsen Sea record of Macellicephaloides sp. $\mathrm{n}$. represents the shallowest record of this otherwise abyssal to hadal genus to date (Pettibone 1976).

Within the topographically complex Pine Island Bay shelf, the strong polychaete depth zonation is accompanied by changes to

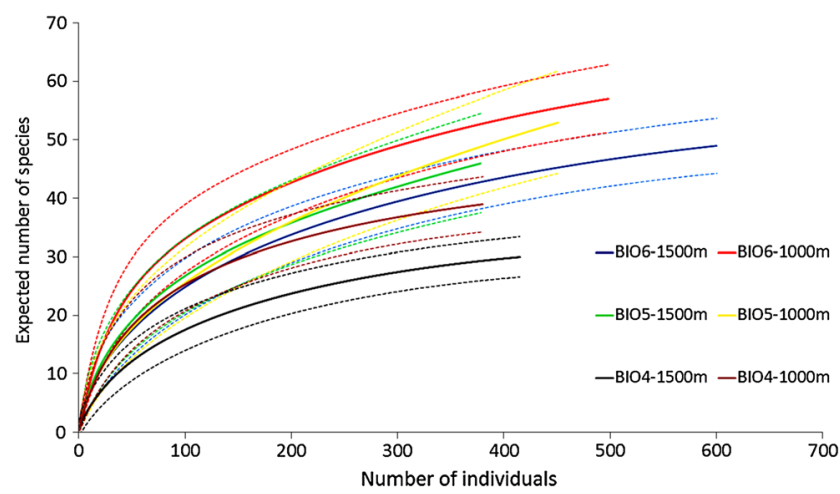

Fig. 8 Comparative polychaete diversity for sites on the Amundsen Sea deep shelf and slope, BIOPEARL II cruise. Sites are based on pooled data from several epibenthic sledge samples based on community analysis. Rarefaction curves represent mean value (full line) with 95\% confidence intervals (dashed lines) 
Table 4 Pooled samples showing total number of individuals, total number of species and summary of comparative diversity statistics for all BIOPEARL sites

\begin{tabular}{|c|c|c|c|c|c|c|c|c|c|c|c|c|}
\hline Sea & Site & $\mathrm{N}$ & $\mathrm{S}$ & $\begin{array}{l}\text { ES } \\
(44)\end{array}$ & $\begin{array}{l}\text { 95\% CI } \\
\text { (low-high) }\end{array}$ & $\begin{array}{l}\text { ES } \\
(600)\end{array}$ & $\begin{array}{l}\text { 95\% CI } \\
\text { (low-high) }\end{array}$ & Chao1 (44) & $\begin{array}{l}\text { 95\% CI } \\
\text { (low-high) }\end{array}$ & $\begin{array}{l}\text { Chao1 } \\
(600)\end{array}$ & $\begin{array}{l}\text { 95\% CI } \\
\text { (low-high) }\end{array}$ & $\begin{array}{l}\text { Biodiversity } \\
\text { classification }\end{array}$ \\
\hline \multicolumn{2}{|c|}{$\begin{array}{l}\text { Total analysed Scotia Sea } \\
\text { (BIOPEARL I - JR144) }\end{array}$} & 5331 & 190 & & & & & & & & & \\
\hline & $\begin{array}{l}\text { South Georgia } \\
\text { (SG) Shelf }\end{array}$ & 702 & 72 & 19.1 & $13.9-24.4$ & 67.5 & $58.5-76.5$ & 36.1 & $23.8-81.7$ & 101.8 & $81-154.7$ & Intermediate \\
\hline & $\begin{array}{l}\text { South Georgia } \\
\text { (SG) Slope }\end{array}$ & 44 & 13 & 13 & $7.3-18.7$ & $\mathrm{n} / \mathrm{a}$ & $\mathrm{n} / \mathrm{a}$ & 23.3 & $15-66$ & $\mathrm{n} / \mathrm{a}$ & $\mathrm{n} / \mathrm{a}$ & Low \\
\hline & $\begin{array}{l}\text { Shag Rocks (SR) } \\
\text { Shelf }\end{array}$ & 731 & 67 & 18.3 & $13.5-23.1$ & 63.1 & $55.7-70.4$ & 38.6 & $23.9-93.8$ & 82.4 & $69.7-120$ & Intermediate \\
\hline & $\begin{array}{l}\text { Southern Thule } \\
\text { (ST) Shelf }\end{array}$ & 1287 & 65 & 13 & $8.4-17.5$ & 49.1 & $40.4-57.7$ & 29.3 & $17.5-78.2$ & 70 & $56-112.5$ & Low \\
\hline & $\begin{array}{l}\text { Southern Thule } \\
\text { (ST) Slope }\end{array}$ & 89 & 18 & 11.9 & $8-15.7$ & $\mathrm{n} / \mathrm{a}$ & $\mathrm{n} / \mathrm{a}$ & 23.7 & $14.6-64.6$ & $\mathrm{n} / \mathrm{a}$ & $\mathrm{n} / \mathrm{a}$ & Low \\
\hline & $\begin{array}{l}\text { Powell Basin } \\
\text { (PB) Shelf }\end{array}$ & 1134 & 98 & 26.6 & $21-32.3$ & 84.2 & $75.6-92.7$ & 54.5 & $36-113.5$ & 102.83 & $91-135.7$ & High \\
\hline & $\begin{array}{l}\text { Powell Basin } \\
\text { (PB) Slope }\end{array}$ & 86 & 22 & 16.1 & $12-20.3$ & $\mathrm{n} / \mathrm{a}$ & $\mathrm{n} / \mathrm{a}$ & 26.1 & $18.5-59$ & $\mathrm{n} / \mathrm{a}$ & $\mathrm{n} / \mathrm{a}$ & Intermediate \\
\hline & $\begin{array}{l}\text { Elephant Island } \\
\text { (EI) Shelf }\end{array}$ & 366 & 44 & 16 & $11.8-20.1$ & $\mathrm{n} / \mathrm{a}$ & $\mathrm{n} / \mathrm{a}$ & 31 & $19.8-75.6$ & $\mathrm{n} / \mathrm{a}$ & $\mathrm{n} / \mathrm{a}$ & Intermediate \\
\hline & $\begin{array}{l}\text { Elephant Island } \\
\text { (EI) Slope }\end{array}$ & 465 & 48 & 16.5 & $11.2-21.8$ & $\mathrm{n} / \mathrm{a}$ & $\mathrm{n} / \mathrm{a}$ & 27.4 & $19-64.3$ & $\mathrm{n} / \mathrm{a}$ & $\mathrm{n} / \mathrm{a}$ & Intermediate \\
\hline & $\begin{array}{l}\text { Livingstone } \\
\text { Island (LI) } \\
\text { Shelf }\end{array}$ & 427 & 49 & 22 & $16.5-27.6$ & $\mathrm{n} / \mathrm{a}$ & $\mathrm{n} / \mathrm{a}$ & 36.1 & $26-73.8$ & $\mathrm{n} / \mathrm{a}$ & $\mathrm{n} / \mathrm{a}$ & Intermediate \\
\hline \multicolumn{2}{|c|}{$\begin{array}{l}\text { Total analysed Amundsen Sea } \\
\text { (BIOPEARL II - JR179) }\end{array}$} & 11,600 & 202 & & & & & & & & & \\
\hline & BIO4-500 m & 3974 & 118 & 20.7 & $15.4-26.1$ & 70.7 & $61.8-79.5$ & 24.5 & $20.1-41$ & 98.8 & $81.1-146.6$ & Intermediate \\
\hline & BIO4-1000 m & 380 & 39 & 17.1 & $13-21.2$ & $\mathrm{n} / \mathrm{a}$ & $\mathrm{n} / \mathrm{a}$ & 27.1 & $19.2-60.5$ & $\mathrm{n} / \mathrm{a}$ & $\mathrm{n} / \mathrm{a}$ & Intermediate \\
\hline & BIO4-1500 m & 415 & 30 & 11.3 & $8.1-14.6$ & $\mathrm{n} / \mathrm{a}$ & $\mathrm{n} / \mathrm{a}$ & 19.7 & $13.1-51.7$ & $\mathrm{n} / \mathrm{a}$ & $\mathrm{n} / \mathrm{a}$ & Low \\
\hline & BIO5-500 m & 3638 & 92 & 18 & $12.2-23.7$ & 52.2 & $42.4-62.6$ & 25.3 & $19.7-50$ & 75.1 & $59.8-124.3$ & Intermediate \\
\hline & BIO5-1000 m & 451 & 53 & 16.6 & $11.6-21.7$ & $\mathrm{n} / \mathrm{a}$ & $\mathrm{n} / \mathrm{a}$ & 31.4 & $20.4-76.5$ & $\mathrm{n} / \mathrm{a}$ & $\mathrm{n} / \mathrm{a}$ & Intermediate \\
\hline & BIO5-1500 m & 378 & 46 & 17.9 & $12.7-23.1$ & $\mathrm{n} / \mathrm{a}$ & $\mathrm{n} / \mathrm{a}$ & 30 & $20.7-67.6$ & $\mathrm{n} / \mathrm{a}$ & $\mathrm{n} / \mathrm{a}$ & Intermediate \\
\hline & BIO3-500 m & 619 & 67 & 25 & $19.6-30.4$ & 70.6 & $64.3-76.9$ & 44.1 & $31.1-88$ & 83.3 & $74.8-109.9$ & Intermediate \\
\hline & BIO6-500 m & 707 & 69 & 21.6 & $16.2-27$ & 67.4 & $59.2-75.6$ & 38.6 & $26.3-83.3$ & 93.9 & $76.8-142$ & Intermediate \\
\hline & BIO6-1000 m & 498 & 57 & 22.8 & $17.6-28$ & $\mathrm{n} / \mathrm{a}$ & $\mathrm{n} / \mathrm{a}$ & 36.9 & $26.8-74$ & $\mathrm{n} / \mathrm{a}$ & $\mathrm{n} / \mathrm{a}$ & Intermediate \\
\hline & BIO6-1500 m & 600 & 49 & 16.4 & $12-20.7$ & 49 & $44.3-53.7$ & 33.9 & $21.5-81.5$ & 54.5 & $50.4-70.5$ & Intermediate \\
\hline Total analysed & $\begin{array}{l}\text { BIOPEARL } \\
\text { program }\end{array}$ & 16,991 & 307 & & & & & & & & & \\
\hline
\end{tabular}

functional groups. In the similarly deep east Antarctic George V Trough a strong zonation pattern was also noted, albeit at macrofaunal level (Beaman and Harris 2005). An observed gradient from suspension to detritus to deposit feeders mirroring the changes in substrate type was likely explained by weakening of the currents inside George V Trough with increasing depths. However, the macrobenthos of Pine Island Bay troughs was dominated by echinoderms across all depths (Linse et al. 2013) and soft sediments dominated all sampling sites. Functionally and ecologically diverse polychaetes have representatives among all feeding groups, even though our chosen sampling apparatus (EBS) was more likely to collect the epibenthic highly mobile, predatory subset of the polychaetes. Although the suspensionfeeding sabellid Jasmineira cf. macrophthalma Ehlers, 1913 was relatively abundant at BIO5-500 $\mathrm{m}$ trough site, generally the polychaete fauna was dominated by motile predators/ detritus feeders (mostly Polynoidae, Glyceridae, Hesionidae and Nephtyidae) and deposit feeders (Acorcirridae, Spionidae, Ophellidae and Fauveliopsidae). An interesting functional split can be seen in trough sites where deposit feeders were dominant alongside motile predators/detritivores in $500 \mathrm{~m}$ horizons, but the deeper sites were entirely dominated by the latter group with a notable absence of deposit feeders. On the open slope at similar depth, the deposit-feeders were still present.

As already hinted earlier, the taxonomic novelty of polychaetes within the previously unsampled, geographically large and topographically complex Amundsen Sea was high. Data published for isopods showed the rate of discovery of new 
species from the Amundsen Sea shelf equals the deep sea (Kaiser et al. 2009; Riehl and Kaiser 2012), while Pabis et al. (2015a) revealed a large number of new tanaid species, particularly in the deep trough sites. The current level of identification for polychaetes enables a preliminary estimate of up to $55 \%$ of species are previously undescribed. The best estimates are currently available for the Polynoidae, which were not only the most abundant, but with 23 species also the most species rich of polychaetes collected. At least seven polynoid species (about 30\%) are new to science and currently under description, with some descriptions already published (Neal et al. 2012).

Although there is a high percentage of species new to science in the Amundsen Sea, not all are likely to represent an endemic fauna. Several of the new Polynoidae species are shared with the deep Weddell Sea, when compared with material from the ANDEEP expeditions (Neal, personal observation) and similar assessment was made for Ampharetidae (Schüller, personal communication). Other known species with wide, even circumpolar distribution such as Austrolaenilla antarctica Bergström, 1916, Austrolaenilla pelagica (Monro, 1930), Glycera kerguelensis McIntosh, 1885 complex, Harmothoe fuligineum (Baird, 1865), Laonice weddellia Hartman, 1978, Euphrosinella cirratoformia (Averincev, 1972), and morphospecies Hesionidae sp. A also form an important component of Amundsen Sea polychaete fauna. It is important to re-iterate that these conclusions are currently drawn from morphological data only. The molecular work on polychaetes in the Southern Ocean to date has been very limited (Riesgo et al. 2015), but Schüller (2010) already demonstrated that Glycera kerguelensis is in fact a complex of cryptic species. This finding is relevant to data presented here as Glycera kerguelensis (as established by morphological examination) was abundant at all depth horizons in the Amundsen Sea. Neal et al. (2014) suggested that a haplotype of Austrolaenilla antarctica from South Georgia may represent a different species to those from the Amundsen and Weddell Seas, while a wide geographic range of Austrolaenilla pelagica between the Amundsen and Ross Seas has been shown. The biogeographic and bathymetric patterns in polychaete morphospecies targeted by Brasier et al. (2016) are currently being investigated further (Brasier, personal communication).

The Scotia Sea. Although the analysis of faunal similarity (Fig. 3a) revealed an existence of a cluster that could be labelled as "Scotia Sea" in comparison to Amundsen Sea fauna, this cluster is very loose and similarity rather low (around $31.86 \%$ ). As in the Amundsen Sea, depth was also the main factor structuring polychaete assemblages. In general, the shelf fauna across different islands sampled was more similar than fauna on the adjacent slope within the same site. However, it is important to stress that sampling at each island was rather limited, with only one epibenthic sledge collected per depth horizon and results should be interpreted with caution as these may in fact be an artefact of undersampling (Fig. 2b).

The sites that were most similar to each other at shelf depth, were not necessarily sites geographically nearest to each other, or similar in geological history or sediment type (e.g. Shag Rock and South Georgia or Livingstone and Elephant Islands). Interestingly, the faunal dissimilarity for close lying, soft-bottomed Elephant and Livingstone Islands was also previously reported for macrobenthos analysed from Agassiz trawls collected during BIOPEARL I expedition (Griffiths et al. 2008). The most "unique" location: very remote, tectonically active, and geological young Southern Thule did not form a separate cluster. Instead its shelf fauna was to some degree similar to the shelf of South Georgia. One explanation for the patterns observed (albeit tentatively due to undersampling) lies in the ocean currents. For example the strong dissimilarity between Shag Rocks and South Georgia has also been reported for other taxa and at different taxonomic levels (López de la Cuadra and García Gómez 2000; Barnes 2008; Pabis et al. 2015a) and restricted gene flow between these two islands was demonstrated for octopus Pareledone turqueti (Allcock et al. 1997). Such observations could be explained by the currents within a deep channel forming a dispersal barrier between Shag Rocks and South Georgia. In the case of Southern Thule, a strong affinity with other archipelagos of the Scotia Arc has been previously reported (e.g. Moyano 2005; Tatiàn et al. 2005; Zelaya 2005; Linse et al. 2006). Kaiser et al. (2008) suggested this might be a result of passive drifting of organisms due to the West Wind Drift or Weddell Gyre especially for groups with planktonic larvae, such as many polychaetes.

While each island in Scotia Sea may represent a distinct polychaete fauna, this is not necessarily a case of endemism and radiation as seen in the distribution of low-dispersal tanaids (Pabis et al. 2015a) and other benthic macro- and megafauna (Griffiths 2010). In fact, many of the polychaete species collected across Scotia Sea are otherwise widely distributed in the Southern Ocean. This conclusion is currently based on morphological evidence alone and may be re-assessed with molecular data (Brasier, personal communication). For example using molecular approach, Linse et al. (2007) already demonstrated support for reproductively isolated populations of bivalve Lissacra notorcadensis across islands of Scotia Arc.

Among the most dominant polychaete fauna were species with known circumpolar distributions (many also abundant in the Amundsen Sea) such Harmothoe fuligienum (Baird, 1865), Laonice weddellia Hartman, 1978, Hesionidae sp. A, Exogone heterosetosa McIntosh, 1885, Orbiniella uniformis Hartman, 1967, Euphrosionopsis antarctica (HartmannSchröder \& Rosenfeldt, 1992), or Paradiopatra antarctica (Monro, 1930). Anobothrus cf. patagonicus (Kinberg, 1866) was abundant on the shelf of South Georgia, mirroring its 
close position to the South American continent. Aurospio foodbancsia, described only recently from the West Antarctic Peninsula (Mincks et al. 2009) has had its range expanded by this study with records from the Amundsen Sea and the slopes of Elephant Island and Southern Thule.

Unlike the polychaetes of the Amundsen Sea, the Scotia Sea fauna tends to be taxonomically relatively well known at least at shelf depth. However, deeper waters may yield species new to science as already demonstrated by Kuklinski et al.'s (2009) work on bryozoans. For example, one of the new species collected in the Amundsen Sea, currently assigned to morphospecies Prionospio sp. B, was also abundant on the slope of the Elephant Island. All polychaetes collected during the BIOPEARL I cruise were fixed in ethanol offering for the Southern Ocean a still-rare opportunity for future molecular studies in general and those of polychaetes in particular (Grant et al. 2011; Riesgo et al. 2015). Such studies will be of interest not only to taxonomy, but to evolutionary questions such as the role of glacial periods, as patterns observed here suggest that species were more likely to survive in shelf refugias, rather than migrating into deeper waters, given the dissimilarity between shelf and slope polychaete fauna.

\section{Large-scale patterns in polychaete species diversity}

Morphology versus molecules The polychaete species diversity presented here is based on morphological identification and is not able to account for crypsis or "missing characters" due to damage of specimens. Polychaetes are prone to fragmentation and most worms were posteriorly incomplete, many polynoidae were missing their scales and it was not practical to dissect jaws and proboscis in many, particularly small specimens. A large number of specimens were also revealed to be juveniles, which can show very different morphology from their adult counterparts (Neal et al. 2014), but knowledge of such developmental stages of Southern Ocean polychaetes is very rare. Recently Brasier et al. (2016) published molecular results on subset of 16 morphospecies from this study, leading to the addition of extremely valuable and rare molecular data for Southern Ocean polychaetes. Out of the 16 species examined, eight were found to contain cryptic species. Whilst 16 species examined out of a total of 307 total morphospecies from the initial morphological sorting is only a small proportion (5\%), this was still the largest study of cryptic speciation in deep-sea, as well as Southern Ocean polychaetes to date. It is clear that species diversity may be still much higher when genetic evidence is presented. The study also highlighted several species that were considered sound morphological species, but some specimens were occasionally overlooked during the initial morphological examination and only secondarily detected after the molecular work was complete. The authors would like to point out that these taxa are present in the large dataset presented here and are not missing, which could potentially be interpreted from the results presented in Brasier et al. (2016). The sorting of over 16,000 polychaete specimens is likely to lead to some oversights, highlighting the usefulness of genetic work as an error-check on morphological work, as well as uncovering true undetected species.

Regional comparisons Currently, there are about 700 polychaete species known from the Southern Ocean (De Broyer and Danis 2011). This means that based on collective effort from just two cruises ( $n=16,991$ included in the species-level analysis) we have recovered just under half of the current species richness $(S=307)$ for the entire Southern Ocean. However, it is important to stress that much of the contribution to this species richness, (particularly in the Amundsen Sea) comes from new, undescribed species. Throughout the identification process, there was a concern that some species that key out to taxa considered cosmopolitan or circumpolar may be "cryptic" species as already discussed (Neal et al. 2014; Brasier et al. 2016). Therefore, the 307 species reported here must be an under-representation of the total polychaete species diversity. The species accumulation curves are still rising, albeit slowly for the shelf sites, (Fig. 2) supporting the idea more species are yet to be discovered from the sampled area, particularly from deeper sites, which were poorly sampled (Table 4, Fig. 2b). A similar number of polychaete species was recovered from each sea, 190 for the Scotia Sea and 202 for Amundsen Sea, although the number of polychaete specimens from Amundsen Sea was more than double that of Scotia Sea. Given that the Scotia Sea samples represent a mosaic of different sites, while the Amundsen Sea is a more homogeneous environment, the higher number of species for sampling effort in the Scotia Sea is not surprising. Only around $24 \%$ of taxa were shared between the two seas, which is slightly higher than the finding of $17 \%$ shared isopods species from shelf depths of both seas (Kaiser et al. 2009).

In wider comparative terms, it is difficult to assess these numbers given the variety of sampling devices used in the past, and the different spatial and bathymetric scales of sampling. Many previous Antarctic benthic projects have used coring devices, which may only have a low degree of species overlap with EBS samples (Hilbig 2004). Only the ANDEEP expeditions have previously used EBS to study polychaetes, concentrating on the slope and abyss (711-3488 m) of the Weddell Sea and resulting in the collection of 10,529 polychaetes and 241 species, many new to science (Schüller et al. 2009). Our data from each sea are thus broadly similar in terms of species richness. However, most polychaetes specimens collected during BIOPEARL expeditions were collected from shelf depths (even though slope depths were also targeted) and here only comparisons with previous coring studies are possible. At a large scale (i.e. in terms of the entire Amundsen or Scotia Sea) the number of species collected 
respectively are rather impressive. The richness of polychaetes species previously reported for the whole of Ross Sea is 146 (Knox and Cameron 1998) while at single bay scale Gambi et al. (1997) reported 77 species from 5768 individuals of polychaetes collected at Terra Nova Bay. Montiel et al. (2005) recorded 199 polychaete species in the Magellan region and 163 in the Weddell Sea, while Hilbig et al. (2006) reported 235 polychaete species from the EASIZ II expedition to Weddell Sea, based on 151 core samples taken between 120 and $2415 \mathrm{~m}$ depth. A study of the deep Atlantic sector of the Southern Ocean using core samples found 175 polychaete species (Ellingsen et al. 2007). The recent update on the state of knowledge of biodiversity from Admiralty Bay, South Shetlands based on more than 3 decades of investigations reported the presence of 162 polychaete species (Sicinski et al. 2010). Two smaller scale datasets available from the Bellingshausen Sea (a region adjacent to both Scotia and Amundsen Sea), reported similar results with 77 species based on 1328 polychaete specimens recorded by (Parapar et al. 2011), while Neal et al. (2011) reported 78 species identified from 1035 individuals.

\section{Diversity comparisons within the Amundsen and Scotia seas}

The polychaete species alpha and beta diversity as measured across wide range of sites in the Amundsen and Scotia Seas (Table 4, Fig. 5-8) can be at best described as widely fluctuating. We decided to classify sites based on their relative species diversity and estimated total species richness into sites with "high", "intermediate", and "low" biodiversity (Table 4).

Sites with high biodiversity Only one site stood out in terms of number of species, with the highest estimate of species richness (98 species from 1132 individuals, see also Table 4, Fig. 5): the Powell Basin shelf in South Orkney Islands (SOI), Scotia Sea. The SOI are an ancient micro-continental fragment, bordering the Scotia Sea and the Weddell Sea, which is likely of significance for biodiversity, particularly the influence of Weddell Sea gyre, which keeps SOI colder than expected for their latitude (Clarke and Leakey 1996). Our findings are in agreement with results from a large-scale biodiversity assessment (Barnes et al. 2008) that reported 1026 marine species from SOI, 822 of them benthic. A study limited to isopods also documented high diversity in this region (Brandt et al. 2007a, 2007b). High diversity reported across different benthic taxa, led in part to the establishment of Marine Protected Area (MPA) south of SOI. Data on polychaetes from this region are rare, thus our findings showing unequivocally high richness of this important component of benthic fauna are of relevance to a future conservation strategy for this region. Additionally, Barnes et al. (2016) reported high carbon "immobilization" by benthos (bryozoans) at SOI, which suggests that benthos of this area is not just biodiverse, but also potentially important in terms of ecosystem services.

Sites with intermediate biodiversity In the Amundsen Sea, diversity varied across the sites and depths, but overall, the Amundsen Sea appears to support diverse assemblages of polychaetes, with most sites falling within what we term "intermediate" biodiversity. Deep sites in particular harbour taxa new to science enhancing not only the Amundsen Sea diversity, but also the overall diversity of the Southern Ocean. The inner trough sites, appear to have slightly depressed diversity in comparison to the outer shelf, mostly owing to large populations of polynoid worms, particularly Harmothoe fuligineum and Austrollaenila antarctica (both adults and juveniles) at $500 \mathrm{~m}$ depth horizons.

In the absence of detailed sample-specific environmental variables, we can only speculate on factors enhancing the biodiversity in the Amundsen Sea. Firstly, its shelf is large, spanning more than $400 \mathrm{~km}$. With the intrusion of Antarctic Deep Water on the shelf giving the Amundsen Sea a deep-sea character in species composition it is possible that the mixture of shelf and deep-sea species found together enhances biodiversity. Further, at the inner Pine Island Bay, the shelf is topographically complex, which may lead to a variety of microhabitats. The evidence for this could be potentially seen from different functional groups supported by different environments (see assemblage discussion).

In some areas of the Amundsen Sea, enhanced productivity might have a positive effect of biodiversity owing to the ability for the site to support larger populations. However, productivity at high levels can also depress biodiversity (e.g. Rosenzweig and Abramsky 1993). This may be the case at the inner shelf sites $\mathrm{BIO} 4$ and $\mathrm{BIO5}$, which have enhanced productivity thanks to their proximity to the Pine Island Polynya (Fig. 1b) (Arrigo et al. 2012; Yager et al. 2012). Large numbers of polychaetes (see Table 4) were collected here, making these sites the most completely sampled BIOPEARL sites (Fig. 7). It is likely that dominance rather than low number of species reduce diversity estimates at these sites as result from Chaol (Table 4) suggest high overall species richness. The dominance comes from the build-up of populations of two deposit feeders in the $\mathrm{BIO} 5$ site, the acrocirrid Flabelligena sp. A and opheliid Ophelina abranchiata. The large populations of deposit feeders suggest an accumulation of sediment and food. These shelf troughs could be considered analogous to submarine canyons, which can have depressed diversity due to high dominance in turn explained by organic enrichment (e. g. Paterson et al. 2016; Gunton et al. 2015). In fact, Ophelina abranchiata has been found to dominate polychaete communities in the canyons on Iberian margin (Paterson et al. 2016) and Whittard canyon in NE Atlantic (Gunton et al. 2015). Finally, many polychaetes collected from trough sites were juveniles (Neal et al. 2014), 
suggestive of recent recruitment, likely as a result of food availability as oligotrophic outer shelf sites did not show such a trend.

In the Scotia Sea, the Shag Rocks (shelf) and South Georgia (shelf) were also found to be of intermediate diversity, with ES(40) values of 17.53 and 18.33, respectively, albeit at the higher end of this range. Whilst the composition of polychaete fauna of these two localities was rather different (Fig. 3c), the species richness of the shelves of Shag Rocks and South Georgia was similar ( $\mathrm{S}=67 / 72$, respectively), with approximately 700 individuals collected at each site (Table 4). The shelves of both South Georgia and Shag Rocks, were labelled biodiversity hotspots in previous investigations (Barnes et al. 2006; Barnes 2008; Hogg et al. 2011), while our results support this trend, we found lower diversity compared to SOI, at least for polychaetes. However, the Chao 1 estimate (Table 4) does support high total species richness, comparable with SOI. A compilation of data by Hogg et al. (2011) showed that the shelf above $700 \mathrm{~m}$ is one of the most species-rich regions of the Southern Ocean with rare and endemic benthos comprising the majority of 1445 species known to date. This richness in benthos around the South Georgia archipelago has been highlighted as one of priorities with respect to conservation and the establishment of MPA (Trathan et al. 2014). Therefore, the dataset on polychaetes provided here further strengthens the existing findings and rationale for the placement of an MPA.

Both islands are geologically old and it is possible to speculate that this permitted high species richness to evolve. Of the current ecological conditions, both shelves are less exposed to winter sea ice-cover, less iceberg scouring and, therefore, disturbance than locations further south. Both islands are the nearest links to the shelf of South America and, therefore, they represent a first meeting point for temperate species extending their ranges south as already seen in non-indigenous terrestrial species (Frenot et al. 2005). As a result, biodiversity could be enhanced by being a meeting point of biota from two regions, South American (Magellan) and true Southern Ocean (Barnes et al. 2009, 2011; Hogg et al. 2011). Indeed, the most common polychaete species found on the South Georgia shelf (at $200 \mathrm{~m}$ station) was Anobothrus cf. patagonicus suggesting linkages to South America, while the other was the highly mobile polynoid Harmothoe fulgineum with a circumpolar distribution, demonstrating links to the Southern Ocean. Importantly for Southern Ocean fauna, this is also a location where the Polar Front reaches its northernmost range with temperature reaching up to $4{ }^{\circ} \mathrm{C}$ in the summer (Holeton et al. 2005) at least in shallow shelf depths, representing the temperature extreme that the current fauna is living in. This is of relevance to predicted rises in regional sea temperatures and ability of most Antarctic ectotherms to cope (Peck et al. 2010). More broadly, on a regional level, Ingels et al. (2012) suggested variable, taxon-specific responses to environmental changes resulting in shifts in diversity, dominance, and trophic group composition with likely consequences for ecosystem functioning.

Elephant Island (shelf, $\mathrm{S}=44$ ) and Livingstone Island (shelf, $\mathrm{S}=49$ ) are another example of sites which despite their geographical proximity support different polychaete assemblages, but similar diversity and species richness. The comparison is enhanced by the fact that a similar number of individuals (ca 350-400, see Table 4) were collected at these sites. On the slope of Elephant Island our data suggest that slopes could in places be as diverse as shelves (Table 4). Despite the similar soft-sediment environments at Elephant and Livingstone Islands, which would be expected to provide good conditions for polychaetes, the species richness was at the lower end of "intermediate" range. It could be argued that collection effort is still rather low, but the results from other polychaete studies from South Shetland Islands corroborate these results. For example, using grab samples from Livingstone and Deception Island San Martín et al. (2000) recovered 3700 specimens of polychaetes belonging to 89 species. Pabis and Sicinski (2012) collected grab samples at Admiralty Bay, South Shetlands and found 76 polychaete species in depths ranging from 200 to $500 \mathrm{~m}$. Comparative analysis by Neal et al. (2011) also showed Admiralty Bay to have a depressed diversity similar to that of species-poor Arctic shelves, although depending on a choice of comparative Arctic site, these results can vary (see Pabis et al. 2015c). There are 162 species known polychaete species from Admiralty Bay based on summary of more than 30 years of research in this area (Sicinski et al. 2010).

\section{Sites with low biodiversity}

Within the already-extreme environment of the Southern Ocean small, isolated and seismically-active islands present even more difficulties for the colonization by fauna. One such example are the South Sandwich Islands in the Scotia Sea. These are geologically young (Dayton 1990), very remote and surrounded by deep waters. The volcanic islands of the South Sandwich archipelago are seismically active even today (e.g. Leat et al. 2003; Patrick et al. 2005). These extreme and highly dynamic environmental conditions result in debris flow deposition, high sedimentation rates and high primary production (Vanhove et al. 2004; Patrick et al. 2005). All factors together represent challenges to faunal colonization on both ecological and evolutionary timescales.

One location of South Sandwich Islands sampled during BIOPEARL I expedition was Southern Thule. Samples were taken at shelf depths $(300 \mathrm{~m}$ and $500 \mathrm{~m})$ and slope depths $(1000 \mathrm{~m}$ and $1500 \mathrm{~m})$. Extreme and disturbed environments are often characterized by high dominance of either opportunist or specialist species, which can locally achieve high densities and reduce the overall biodiversity (Gray 1989). The patterns in diversity of polychaete species indeed corroborate this 
expectation (see Fig. 5-8, Table 4). Southern Thule was shown to have high levels of dominance in all depth horizons (especially at slope depths), making this a site of "low" biodiversity. The highly dynamic, narrow, steep, and gravitationally unstable shelf of Southern Thule is dominated by mobile predatory species of Syllidae, whilst the deeper slopes are home to large populations of deposit-feeding opportunistic Spionidae.

Other studies conducted in Southern Thule have shown a similar pattern for other taxa and found impoverished diversity for isopods (Brandt 1991), bryozoans (López de la Cuadra and García Gómez 2000; Moyano 2005), bivalves and gastropods (Zelaya 2005; Linse et al. 2006), and malacostracan crustaceans (Kaiser et al. 2008), suggesting that the local environmental conditions exert a strong influence on all benthos. However, the large number of rare species (singletons) taken into account by the Chaol estimator suggest that total species richness of Southern Thule shelf could ultimately be high for polychaetes (Table 4) making it in fact a potentially high biodiversity site if future sampling effort was increased.

\section{Conclusions}

The Scotia and Amundsen Seas support distinct polychaete assemblages with depth shown as the main factor structuring these assemblages in both seas, countering the prevalent notion of extended eurybathy of the Southern Ocean benthos. The previously-unsampled Amundsen Sea is shown to be diverse, harbouring many species new to science. Polychaete fauna of the inner shelf of the Amundsen Sea has also been shown to be deep-sea in character, likely due to intrusion of Circumpolar Deep Water onto shelf. Both seas are spanning regions with "high", "intermediate", and "low" biodiversity, with some sites undersampled (particularly those from deeper waters), broadly in line with overall "intermediate" levels of biodiversity when compared globally. In the Scotia Sea, polychaete data support the notion of high biodiversity of waters around South Orkneys (Powell Basin), South Georgia and Shag Rocks, all areas selected for environmental protection. The extreme environment of Southern Thule has biodiversity suppressed owing to high dominance by few species, but overall this area could be high in species richness if sampling effort was increased. Finally, BIOPEARL samples represent one of the largest single collections of benthic fauna in the Southern Ocean undertaken with comparative sampling methods. The fact that the raw data is made available and a significant proportion of the material has been preserved for molecular studies (see Supplementary Information, DarwinCore Archive, http://dx.doi.org/10.5519/ 0068114) renders these samples very valuable for current and future research addressing questions of circumpolarity, genetic connectivity, faunal survival strategies during the past glacial periods, as well as the origins of the Southern Ocean fauna.
Acknowledgements The BIOPEARL project required a large amount of macrofaunal sorting over several years, and for this in particular we are indebted to Rebekah Baker, David Barnes, Ondine Cornubert, Stefanie Kaiser, Adam Reed, Chester Sands, and Marla Spencer. Imperial College Masters students Elizabeth Bryce and Thomas Writer assisted with specimen identification. We also thank Brian Bett for his support with the use of EstimateS software. NHM London volunteer Cate Huque assisted with the Darwin Core database and assembling of Fig. 6 . We would also like to thank Huw Griffiths for providing the map in Fig. 1a and Olivia MartinSanchez for providing maps in Fig. 1b,c for this publication. We are particularly grateful to Peter Enderlein for his expertise in sample collection and cruise leadership during the BIOPEARL II expedition. Further thanks go to the crew of James Clark Ross on both BIOPEARL expeditions. Thanks also to Muriel Rabone for assistance with DarwinCore archive. Post-cruise sorting and analysis was also enabled by series of small internal grants provided by the Natural History Museum, London, as well as many hours of voluntary work by all people involved.

Open Access This article is distributed under the terms of the Creative Commons Attribution 4.0 International License (http:// creativecommons.org/licenses/by/4.0/), which permits unrestricted use, distribution, and reproduction in any medium, provided you give appropriate credit to the original author(s) and the source, provide a link to the Creative Commons license, and indicate if changes were made.

\section{References}

Alderkamp AC, Mills MM, van Dijken G L et al. (2012) Iron from melting glaciers fuels phytoplankton blooms in the Amundsen Sea (Southern Ocean). Phytoplankton characteristics and productivity Deep Sea Res Part II 71-76:32-48 doi:10.1016/j.dsr2.2012.03.005

Allcock AL, Brierley AS, Thorpe JP, Rodhouse PG (1997) Restricted gene flow and evolutionary divergence between geographically separated populations of the Antarctic octopus Pareledone turqueti. Mar Biol 129(1):97-102

Arntz W, Brey T, Gallardo VA (1994) Antarctic zoobenthos. Oceanography and Mar Biol 32:241-304

Arrigo KR, Lowry KE, Van DGL (2012) Deep-Sea research II annual changes in sea ice and phytoplankton in polynyas of the Amundsen Sea , Antarctica. Deep-Sea Res II Top Stud Oceanogr 71-76:5-15. doi:10.1016/j.dsr2.2012.03.006

Barker PF (2001) Scotia Sea regional tectonic evolution: implications for mantle flow and palaeocirculation. Earth Sci Rev 55:1-39. doi:10. 1016/S0012-8252(01)00055-1

Barnes DKA, Linse K, Waller C, Morely S, Enderlein P, Fraser KPP, Brown M (2006) Shallow benthic fauna communities of South Georgia Island. Polar Biol 29(3):223-228. doi:10.1007/s00300005-0042-0

Barnes DKA (2008) A benthic richness hotspot in the Southern Ocean: slope and shelf cryptic benthos of Shag Rocks. Antarct Sci 20:263270. doi:10.1017/S0954102008001089

Barnes DKA, Kaiser S, Griffiths HJ et al. (2008) Marine, intertidal, freshwater and terrestrial biodiversity of an isolated polar archipelago. $\mathrm{J}$ Biogeogr 756-769. doi:10.1111/j.1365-2699.2008.02030.x

Barnes DKA, Griffiths HJ, Kaiser S (2009) Geographic range shift responses to climate change by Antarctic benthos: where we should look. Mar Ecol-Prog Ser 393:13-26 doi.org/10.3354/meps08246

Barnes DKA, Kuklinski P (2010) Bryozoans of the Weddell Sea continental shelf, slope and abyss: did marine life colonize the Antarctic shelf from deep water, outlying islands or in situ refugia following glaciations? J Biogeogr 37(9):1648-1656. doi:10.1111/j.1365-2699. 2010.02320.x 
Barnes DKA, Martin AC, Brickle P et al (2011) The need to implement the convention on biological diversity at the high latitude site, South Georgia. Antarct Sci 23:323-331. doi:10.1017/ S0954102011000253

Barnes DKA, Ireland L, Hogg OT, Morley S, Enderlein P, Sands CJ (2016) Why is the south Orkney Island shelf (the world's first high seas marine protected area) a carbon immobilization hotspot? Glob Chang Biol 22:1110-1120. doi:10.1111/gcb.13157

Beaman RJ, Harris PT (2005) Bioregionalization of the George V shelf, East Antarctica. Cont Shelf Res 25(14):1657-1691. doi:10.1016/j. csr.2005.04.013

Blake JA (2015) New species of Scalibregmatidae (Annelida, Polychaeta) from the East Antarctic peninsula including a description of the ecology and post-larval development of species of Scalibregma and Oligobregma. Zootaxa 4033(1):57-93. doi:10. 11646/zootaxa.4033.1.3

Blake JA (2016) Kirkegaardia (Polychaeta, Cirratulidae), new name for Monticellina Laubier, preoccupied in the Rhabdocoela, together with new records and descriptions of eight previously known and sixteen new species from the Atlantic, Pacific, and southern oceans. Zootaxa 4166(1):1-93. doi:10.11646/zootaxa.4166.1.1

Brandt A (1991) Colonization of the Antarctic shelf by the isopoda (Crustacea, malacostraca). Ber Polarforsch 98:1-240

Brandt A (2005) Evolution of Antarctic biodiversity in the context of the past: the importance of the Southern Ocean deep sea. Antarct Sci 17(4):509. doi:10.1017/S0954102005002932

Brandt A, Brix S, Brökeland W, Choudhury M et al (2007a) Deep-sea isopod biodiversity, distribution and endemism in the Atlantic sector of the Southern Ocean - results from the ANDEEP I-III expeditions. Deep Sea Res Part II Top Stud Oceanogr 54:1760-1775. doi:10. 1016/j.dsr2.2007.07.015

Brandt A, Gooday AJ, Brandao SN et al (2007b) First insights into the biodiversity and biogeography of the Southern Ocean deep sea. Nature 447(7142):307-311. doi:10.1038/nature05827

Brandt A, Linse K, Schüller M (2009) Bathymetric distribution patterns of Southern Ocean macrofaunal taxa: Bivalvia, Gastropoda, isopoda and Polychaeta. Deep Res Part I Oceanogr Res Pap 56(11):20132025. doi:10.1016/j.dsr.2009.06.007

Brandt A, Griffiths H, Gutt J, Linse K, Schiaparelli S, Ballerini T, Danis B, Pfannkuche O (2014) Challenges of deep-sea biodiversity assessments in the Southern Ocean. Adv Polar Sci 25(3):204-212. doi:10. 13679/j.advps.2014.3.00204

Brasier MJ, Wiklund H, Neal L, Jeffreys R, Linse K, Ruhl H, Glover AG (2016) DNA barcoding uncovers cryptic diversity in 50\% of deepsea Antarctic polychaetes. R Soc Open Sci 3(11):160432. doi:10. 1098/rsos. 160432

Brenke N (2005) An epibenthic sledge for operations on marine soft bottom and bedrock. J Mar Technol Soc 39(2):10-19. doi:10. 4031/002533205787444015

Brey T, Dahm C, Gorny M, Klages M, Stiller M, Arntz WE (1996) Do Antarctic benthic invertebrates show an extended level of eurybathy? Antarct Sci 8(01):3-6. doi:10.1017/ S0954102096000028

Chao A (1984) Non-parametric estimation of the number of classes in a population. Scand J Stat 11:265-270

Chapelle G, Peck LS (1999) Polar gigantism dictated by oxygen availability. Nature 399(6732):114-115. doi:10.1038/20099

Clarke A (1996) Benthic marine habitats in Antarctica. In: Ross RM, Hofmann EE, Quetin LB (eds) Foundations for ecological research west of the Antarctic peninsula. American Geophysical Union, Washington, D.C., pp 123-133

Clarke A, Leakey RJG (1996) The seasonal cycle of phytoplankton, macronutrients, and the microbial community in a nearshore antarctic marine ecosystem. Limnol Oceanogr 41(6):1281-1294. doi:10. 4319/1o.1996.41.6.1281
Clarke A, Johnston NM (2003) Antarctic marine benthic diversity. Oceanogr Mar Biol 41:47-114

Clarke A, Aronson RB, Crame JA, Gili J-M, Blake DB (2004) Evolution and diversity of the benthic fauna of the Southern Ocean continental shelf. Antarct Sci 16(4):559-568. doi:10.1017/ S0954102004002329

Clarke KR, Gorley RN (2006) PRIMER v6: User Manual/Tutorial. PRIMER-E, Plymouth

Colwell RK (2009) EstimateS: Statistical estimation of species richness and shared species from samples. Version 8.2. User's Guide and application. Available: http://purl.oclc.org/estimates.

Crame JA (2000) Evolution of taxonomic diversity gradients in the marine realm: evidence from the composition of recent bivalve faunas. Palaeogeogr Palaeoclimatol Palaeoecol 26(2):188-214. doi:10. 1666/0094-8373(2000)026<0188:EOTDGI $>2.0 . C O ; 2$

Dayton PK (1990) Polar benthos. In: Smith O (ed) Polar oceanography, Part B, Chemistry, biology and geology. Academic Press, London, pp 631-685

De Broyer C, Danis B (2011) How many species in the Southern Ocean? Towards a dynamic inventory of the Antarctic marine species. Deep Sea Res Part II Top Stud Oceanogr 58(1):5-17. doi:10.1016/j.dsr2. 2010.10.007

Dell RK (1965) Marine biology. In: Hatherton T (ed) Antarctica. AH \& AW Reed, Wellington, pp 129-157

Dell RK (1972) Antarctic benthos. Adv Mar Biol 10:1-216. doi:10.1016/ S0065-2881(08)60416-2

Ellingsen KE, Brandt A, Ebbe B, Linse K (2007) Diversity and species distribution of polychaetes, isopods and bivalves in the Atlantic sector of the deep Southern Ocean. Polar Biol 30(10):1265-1273. doi:10.1007/s00300-007-0287-x

Evans J, Dowdeswell JA, Cofaigh CÓ, Benham TJ, Anderson JB (2006) Extent and dynamics of the West Antarctic ice sheet on the outer continental shelf of Pine Island bay during the last glaciation. Mar Geol 230:53-72. doi:10.1016/j.margeo.2006.04.001

Frenot Y, Chown SL, Whinam J, Selkirk PM, Convey P, Skotnicki M, Bergstrom DM (2005) Biological invasions in the Antarctic: extent, impacts and implications. Biol Rev Camb Philos Soc 80(1):45-72. doi:10.1017/S1464793104006542

Gage JD, May RM (1993) A dip into the deep seas. Nature 365(6447): 609-610. doi:10.1038/365609a0

Gage JD, Tyler PA (1991) Deep-sea biology: a natural history of organisms at the deep-sea floor. Cambridge University Press, Cambridge

Gallardo VA (1977) Large benthic microbial communities in sulphide biota under Peru-Chile subsurface countercurrent. Nature 268: 331-332. doi:10.1038/268331a0

Gambi MC, Zoologica S, Dohrn A (1997) Polychaete populations of the shallow soft bottoms off Terra Nova Bay (Ross Sea, Antarctica): Polychaete populations of the shallow soft bottoms off Terra Nova Bay (Ross Sea, Antarctica): distribution, diversity and biomass. Polar Biol 17:199-210. doi:10.1007/s003000050123

Glover AG, Smith CR, Mincks SL, Sumida PYG, Thurber AR (2008) Macrofaunal abundance and composition on the West Antarctic peninsula continental shelf: evidence for a sediment 'food bank' and similarities to deep-sea habitats. Deep Res Part II Top Stud Oceanogr 55(22-23):2491-2501. doi:10.1016/j.dsr2.2008.06.008

Glover AG, Dahlgren TG, Wiklund H, Mohrbeck I, Smith CR (2016) An end-to-end DNA taxonomy methodology for benthic biodiversity survey in the clarion-Clipperton zone, Central Pacific abyss. J Mar Sci Eng 25:4(1):2. doi: 10.3390/jmse4010002

Grant RA, Griffiths HJ, Steinke D, Wadley V, Linse K (2011) Antarctic DNA barcoding: a drop in the ocean? Polar Biol 34(5):775-780. doi:10.1007/s00300-010-0932-7

Gray JS (2001) Marine diversity: the paradigms in patterns of species richness examined. Sci Mar 65(2):41-56. doi:10.3989/scimar. $2001.65 \mathrm{~s} 241$ 
Gray JS (1989) Effects of environmental stress on species rich assemblages. Biol J Linnean Soc 37(1-2):19-32

Griffiths HJ, Linse K, Barnes DKA (2008) Distribution of macrobenthic taxa across the Scotia arc, Southern Ocean. Ant Sci 20(3):213-226. doi:10.1017/S0954102008001168

Griffiths HJ (2010) Antarctic marine biodiversity - what do we know about the distribution of life in the southern ocean? PLoS One 5(8). doi:10.1371/journal.pone.0011683

Griffiths HJ, Danis B, Clarke A (2011) Quantifying Antarctic marine biodiversity: the SCARMarBIN data portal. Deep Res Part II Top Stud Oceanogr 58(1-2):18-29. doi:10.1016/j.dsr2.2010.10.008

Grotov AS, Nechaev DA, Panteleev GG et al (1998) Large-scale circulation in the Bellingshausen and Amundsen seas as a variational inverse of climatological data. J Geophys Res 103(C6):1301113022. doi:10.1029/98JC00449

Gunton LM, Neal L, Gooday AJ, Bett BJ, Glover AG (2015) Benthic polychaete diversity patterns and community structure in the Whittard canyon system and adjacent slope (NE Atlantic). Deep Sea Res Part 1 Oceanogr Res Pap 106:42-54. doi:10.1016/j.dsr. 2015.07.004

Gutt J, Piepenburg D (2003) Scale-dependent impact on diversity of Antarctic benthos caused by grounding of icebergs. Mar Ecol Prog Ser 253:77-83. doi:10.3354/meps253077

Gutt J, Sirenko BI, Smirnov IS et al (2004) How many macrozoobenthic species might inhabit the Antarctic shelf? Antarct Sci 16:11-16. doi: $10.1017 / \mathrm{S} 0954102004001750$

Hilbig B (2004) Polychaetes of the deep Weddell and Scotia seas composition and zoogeographical links. Deep Sea Res Part II Top Stud Oceanogr 51:1817-1825. doi:10.1016/j.dsr2.2004.07.015

Hilbig B, Gerdes D, Montiel A (2006) Distribution patterns and biodiversity in polychaete communities of the Weddell Sea and Antarctic peninsula area (Southern Ocean). J Mar Biol Assoc United Kingdom 86(04):711-725

Hogg OT, Barnes DKA, Griffiths HJ (2011) Highly diverse, poorly studied and uniquely threatened by climate change: an assessment of marine biodiversity on South Georgia's continental shelf. PLoS One 6(5). doi:10.1371/journal.pone.0019795

Holeton CL, Nedelec F, Sanders R, Brown L, Moore CM, Stevens DP, Heywood KJ, Statham PJ, Lucas CH (2005) Physiological state of phytoplankton communities in the Southwest Atlantic sector of the Southern Ocean, as measured by fast repetition rate fluorometry. Polar Biol 29(1):44-52. doi:10.1007/s00300-005-0028-y

Huybrechts P (2002) Sea-level changes at the LGM from ice-dynamical reconstructions of the Greenland and Antarctica ice sheets during the glacial cycles. Quat Sci Rev 21:203-231

Ingels J, Vanreusel A, Brandt A et al (2012) Possible effects of global environmental changes on Antarctic benthos: a synthesis across five major taxa. Ecol Evol 2(2):453-485. doi:10.1002/ece3.96

Jacobs SS, Jenkins A, Giulivi CF, Dutrieux P (2011) Stronger ocean circulation and increased melting under Pine Island Glacier ice shelf. Nat Geosci 4(8):519-523. doi:10.1038/NGEO1188

Kaiser S, Barnes DKA, Linse K, Brandt A (2008) Epibenthic macrofauna associated with the shelf and slope of a young and isolated Southern Ocean island. Antarct Sci 20:281-290. doi:10.1017/ S0954102008001107

Kaiser S, Barnes DKA, Sands CJ, Brandt A (2009) Biodiversity of an unknown Antarctic Sea: assessing isopod richness and abundance in the first benthic survey of the Amundsen continental shelf. Mar Biodivers 39(1):27-43. doi:10.1007/s12526-009-0004-9

Kaiser S, Griffiths HJ, Barnes DK, Brandão SN, Brandt A, O'Brien PE (2011) Is there a distinct continental slope fauna in the Antarctic? Deep Sea Res Part II Top Stud Oceanogr 31:58(1):91-104. doi:10. 1016/j.dsr2.2010.05.017

Knox GA, Cameron DB (1998) The marine Fauna of the Ross Sea: Polychaeta. NIWA Biodiversity Memoir 108:1-125
Kuklinski P, Barnes DKA, James RRS, Ross C (2009) A new genus and three new species of Antarctic cheilostome Bryozoa. Polar Biol 32(9):1251-1259. doi:10.1007/s00300-009-0621-6

Kussakin OG (1973) Peculiarities of the geographical and vertical distribution of marine isopods and the problem of deep-sea fauna origin. Mar Biol 23(1):19-34. doi:10.1007/BF00394108

Leat PT, Smellie JL, Millar IL, Larter RD (2003) Magmatism in the South Sandwich arc. In: Larter RD, Leat PT (eds) Intraoceanic subduction systems: tectonic and magmatic processes. Geological Society, London, Special Publications, 219(1):285-313.

Linse K, Griffiths HJ, Barnes DKA et al (2006) Biodiversity and biogeography of Antarctic and sub-Antarctic Mollusca. Deep Sea Res Part II Top Stud Oceanogr 53:985-1008. doi:10.1016/j. dsr2.2006. 05.003

Linse K, Cope T, Lörz A-N et al (2007) Is the Scotia Sea a centre of Antarctic marine diversification? Some evidence of cryptic speciation in the circum-Antarctic bivalve Lissarca notorcadensis (Arcoidea: Philobryidae). Polar Biol 30(8):1059-1068. doi:10. 1007/s00300-007-0265-3

Linse K, Griffiths HJ, Barnes DKA, Brandt A, Davey N, David B, Enderlein P (2013) The macro- and megabenthic fauna on the continental shelf of the eastern Amundsen Sea. Antarc Cont Shelf Res 68:80-90. doi:10.1016/j.csr.2013.08.012

Lipps JH, Hickman CS (1982) Origin, age and evolution of Antarctic and deep-sea faunas. In: Ernst WG, Morin JG (eds) The environment of the deep sea (Rubey volume II). Prentice Hall, Englewood Cliffs, NJ, pp 325-356

López de la Cuadra CM, García Gómez JC (2000) The Cheilostomate Bryozoa (Bryozoa: Cheilostomatida) collected by the Spanish'Antartida 8611'expedition to the Scotia arc and south Shetland Islands. J Nat Hist 34(5):755-772

López E (2011) A new species of Laonice (Spionidae, Polychaeta, Annelida) from Bellingshausen Sea (West Antarctica). Helgol Mar Res 65:257-261. doi:10.1007/s10152-011-0248-1

Lowe AL, Anderson JB (2002) Reconstruction of the West Antarctic ice sheet in Pine Island bay during the last glacial maximum and its subsequent retreat history. Quat Sci Rev 21:1879-1897. doi:10. 1016/S0277-3791(02)00006-9

Lowry JK (1975) Soft bottom macrobenthic community of Arthur Harbor, Antarctica. In: Pawson DL (ed) Biology of the Antarctic seas V, Antarctic research series 23. American Geophysical Union, Washington, pp 1-19

Mincks SL, Dyal PL, Paterson GLJ, Smith CR, Glover AG (2009) A new species of Aurospio (Polychaeta, Spionidae) from the Antarctic shelf, with analysis of its ecology, reproductive biology and evolutionary history. Mar Ecol 30(2):181-197. doi:10.1111/j.1439 0485. 2008.00265.x

Montiel A, Gerdes D, Hilbig B, Arntz WE (2005) Polychaete assemblages on the Magellan and Weddell Sea shelves: comparative ecological evaluation. Mar Ecol Prog Ser 297:189-202. doi:10.3354/ meps 297189

Moyano HI (2005) Scotia arc bryozoans from the LAMPOS expedition: a narrow bridge between two different faunas. Sci Mar 69(2):103-112

Moreau C, Linse K, Griffiths HJ, Barnes DKA, Kaiser S, Glover A, Sands C, Strugnell J, Enderlein P, Geissler P (2013) Amundsen Sea Mollusca from the BIOPEARL II expedition. ZooKeys 294: 1-8. doi:10.3897/zookeys.294.4796

Neal L, Mincks-Hardy SL, Smith CR, Glover AG (2011) Polychaete species diversity on the west antarctic peninsula deep continental shelf. Mar Ecol Prog Ser 428:119-134. doi:10.3354/meps09012

Neal L, Barnich R, Wiklund H, Glover AG (2012) A new genus and species of Polynoidae (Annelida, Polychaeta) from Pine Island bay, Amundsen Sea, Southern Ocean-a region of high taxonomic novelty. Zootaxa 3542:80-88

Neal L, Wiklund H, Muir AI, Linse K, Glover AG (2014) The identity of juvenile Polynoidae (Annelida) in the Southern Ocean revealed by 
DNA taxonomy, with notes on the status of Herdmanella gracilis Ehlers sensu Augener Mem. Museum Victoria 71:203-216

Pabis K, Sicinski J (2012) Is polychaete diversity in the deep sublittoral of an Antarctic fiord related to habitat complexity? Pol Polar Res 33(2): 181-197. doi:10.2478/v10183-012-0009-0

Pabis K, Błażewicz-Paszkowycz M, Jóźwiak P, Barnes DKA (2015a) Tanaidacea of the Amundsen and Scotia seas : an unexplored diversity. Antarct Sci 27(1):19-30. doi:10.1017/S0954102014000303

Pabis K, Jóźwiak P, Lörz AN, Schnabel K, Błażewicz-Paszkowycz M (2015b) First insights into the deep-sea tanaidacean fauna of the Ross Sea: species richness and composition across the shelf break, slope and abyss. Polar Biol 38(9):1429-1437. doi:10.1007/s00300015-1706-Z

Pabis K, Kędra M, Gromisz S (2015c) Distinct or similar? Soft bottom polychaete diversity in Arctic and Antarctic glacial fjords. Hydrobiologia 742:279-294. doi:10.1007/s10750-014-1991-5

Parapar J, López E, Gambi MC, Nuñez J, Ramos A (2011) Quantitative analysis of soft-bottom polychaetes of the Bellingshausen Sea and Gerlache Strait (Antarctica). Polar Biol 34(5):715-730. doi:10. 1007/s00300-010-0927-4

Paterson GLJ, Neal L, Altamira I, Soto EH, Smith CR, Menot L, Glover AG (2016) New Prionospio and Aurospio species from the deep sea (Annelida: Polychaeta). Zootaxa 4092(1):1-32. doi:10.11646/ zootaxa.4092.1.1

Patrick MR, Smellie JL, Harris AJ, Wright R, Dean K, Izbekov P, Garbeil H, Pilger E (2005) First recorded eruption of mount Belinda volcano (Montagu Island), south Sandwich Islands. Bull Volcanol 67(5): 415-422. doi:10.1007/s00445-004-0382-6

Pearse JS (1991) Reproduction of Antartic benthic marine invertebrates: tempos, modes, and timing. Am Zool 31:65-80

Peck LS (2002) Ecophysiology of Antarctic marine ectotherms: limits to life. Polar Biol 25:31-40. doi:10.1007/s003000100308

Peck LS, Morley SA, Clark MS (2010) Poor acclimation capacities in Antarctic marine ectotherms. Mar Biol 157(9):2051-2059. doi:10. 1007/s00227-010-1473-x

Pettibone MH (1976) Revision of the Genus Macellicephala McIntosh and the subfamily Macellicephalinae Hartmann-Schröder (Polychaeta, Polynoidae). Smithsonian Institution Press.

Rex MA, Stuart CT, Hessler RR, Allen JA, Sanders HL, Wilson GDF (1993) Global-scale latitudinal patterns of species diversity in the deep-sea benthos. Nature 365:636

Rex MA, Etter RJ (2010) Deep-sea biodiversity: pattern and scale. Harvard University Press, Harvard

Rignot E, Jacobs SS (2002) Rapid bottom melting widespread near Antarctic ice sheet grounding lines. Science 14:296(5575):2020 2023. doi: $10.1126 /$ science. 1070942

Richardson MD, Hedgpeth JW (1977) Antarctic soft-bottom, macrobenthic community adaptations to a cold, stable, highly productive, glacially affected environment. In Adaptations within Antarctic ecosystems: proceedings of the third SCAR symposium on Antarctic biology, 181-96

Riehl T, Kaiser S (2012) Conquered from the Deep Sea? A new Deep-Sea isopod species from the Antarctic shelf shows pattern of recent colonization. PLoS One 7(11):36-38. doi:10.1371/journal.pone. 0049354

Riesgo A, Taboada S, Avila C (2015) Evolutionary patterns in Antarctic marine invertebrates: an update on molecular studies. Mar Genomics 23:1-13. doi:10.1016/j.margen.2015.07.005

Rohde K (1992) Latitudinal gradients in species diversity: the search for the primary cause. Oikos 1:514-527

Rosenzweig ML, Abramsky Z (1993) How are diversity and productivity related? In: Schluter D (ed) Ricklefs RE. University of Chicago Press, Species diversity in ecological communities, pp 52-65

Sanders HL (1968) Marine benthic diversity: a comparative study. Am Nat 102(925):243-282
San Martín GS, Parapar J, García FJ, Redondo MS (2000) Quantitative analysis of soft bottoms infaunal macrobenthic polychaetes from south Shetland Islands (Antarctica). Bull Mar Sci 67(1):83-102

Schüller M, Ebbe B (2007) Global distributional patterns of selected deep-sea Polychaeta (Annelida) from the Southern Ocean. Deep Res Part II Top Stud Oceanogr 54(16-17):1737-1751. doi:10. 1016/j.dsr2.2007.07.005

Schüller M, Ebbe B, Wägele JW (2009) Community structure and diversity of polychaetes (Annelida) in the deep Weddell Sea (Southern Ocean) and adjacent basins. Mar Biodivers 39(2):95-108. doi:10. 1007/s12526-009-0009-4

Schüller M (2010) Evidence for a role of bathymetry and emergence in speciation in the genus Glycera (Glyceridae, Polychaeta) from the deep eastern Weddell Sea. Polar Biol 34(4):549-564. doi:10.1007/ s00300-010-0913-x

Schüller M, Jirkov IA (2013) New Ampharetidae (Polychaeta) from the deep Southern Ocean and shallow Patagonian waters. Zootaxa 3692(1):204-237. doi:10.11646/zootaxa.3692.1.11

Sicinski J, Jazdzewski K, De Broyer C et al (2010) Admiralty Bay benthos diversity - a census of a complex polar ecosystem. Deep Sea Res Part II Top Stud Oceanogr 58(1):30-48. doi:10.1016/j.dsr2. 2010.09.005

Smale DA, Barnes DKA (2008) Likely responses of the Antarctic benthos to climate-related changes in physical disturbance during the 21 st century, based primarily on evidence from the West Antarctic peninsula region. Ecography 31(3):289-305. doi:10.1111/j.09067590.2008.05456.x

Smith JA, Andersen TJ, Shortt M et al (2016) Sub-ice-shelf sediments record history of twentieth-century retreat of Pine Island Glacier. Nature 541:77-80. doi:10.1038/nature20136

Tatiàn M, Antacli JC, Sahade R (2005) Ascidians (Tunicata, Ascidiacea): species distribution along the Scotia arc. Sci Mar 69(S2):205-214

Thatje S, Hillenbrand CD, Larter R (2005) On the origin of Antarctic marine benthic community structure Antarctic ice sheet melting in the Southeast Pacific. Trends Ecol Evol 20:534-540. doi:10.1016/j. tree.2005.07.010

Thoma M, Jenkins A, Holland D, Jacobs S (2008) Modelling circumpolar deep water intrusions on the Amundsen Sea continental shelf. Geophys Res Lett 35:L18602. doi:10.1029/2008GL034939

Thomas R, Rignot E, Casassa G et al (2004) Accelerated sea-level rise from West Antarctica. Science 8 306(5694):255-258. doi:10.1126/ science. 1099650

Thomson MRA (2004) Geological and palaeenvironmental history of the Scotia Sea region as a basis for biological interpretation. Deep Sea Res Part II Top Stud Oceanogr 51:1467-1487. doi:10.1016/j.dsr2. 2004.06.021

Thorson G (1950) Reproductive and larval ecology of marine bottom invertebrates. Biol Rev 25(1):1-45

Trathan PN, Collins MA, Grant SM, Belchier M, Barnes DKA, Brown J, Staniland IJ (2014) The South Georgia and the South Sandwich Islands MPA: Protecting A Biodiverse Oceanic Island Chain Situated in the Flow of the Antarctic Circumpolar Current. Adv Mar Biol. (69):15-78. doi:10.1016/ B978-0-12-800214-8.00002-5

Vanhove S, Vermeeren H, Vanreusel A (2004) Meiofauna towards the south Sandwich trench $(750-6300 \mathrm{~m})$, focus on nematodes. Deep Sea Res Part II Top Stud Oceanogr 51(14):1665-1687. doi:10. 1016/j.dsr2.2004.06.029

Yager PL, Sherrell LM, Stammerjohn SE, Alderkamp AC, Schofield O, Abrahamsen EP, Arrigo KR, Bertilsson S, Garay D, Guerrero R, Lowry KE (2012) ASPIRE: the Amundsen Sea Polynya international research expedition. Oceanography 25(3):40-53. doi:10.5670/ oceanog. 2012.73

Zelaya DG (2005) The bivalves from the Scotia arc islands: species richness and faunistic affinities. Sci Mar 69(2):113-122. doi:10.3989/ scimar.2005.69s 2113 